\title{
ELECTRONIC SERVICE OF DOCUMENTS. NATIONAL AND INTERNATIONAL ASPECTS
}

Fernando GASCÓN INCHAUSTI

Catedrático de Derecho Procesal

Universidad Complutense de Madrid

Trabajo publicado en «Electronic Service of Documents. National and International Aspects», en Electronic Technology and Civil Procedure: New Paths to Justice from Around the World, obra colectiva coordinada por Miklós Kengyel y Zoltán Nemessányi, Ed. Springer, Dordrecht-Heidelberg-New York-London, 2012, 329 págs., pp. 137-180. ISBN 978-94-007-4071-6. 


\title{
ELECTRONIC SERVICE OF DOCUMENTS NATIONAL AND INTERNATIONAL ASPECTS
}

\author{
Fernando GASCÓN INCHAUSTI
}

\begin{abstract}
1. E-Justice AND E-SERVicE: PREVIOUS CONSIDERATIONS. - 2. NATIONAL REGULATIONS CONCERNING E-FILING AND E-SERVICE OF DOCUMENTS: AN OVERVIEW: 2.1. Austria; 2.2. Germany; 2.3. France; 2.4. Italy; 2.5. Spain; 2.6. Brazil; 2.7. United States of America; 2.8. England; 2.9. Other European countries. - 3. E-Service at InTERnAtional Courts: 3.1. The Court of Justice of the European Union; 3.2. The European Court of Human Rights; 3.3. The Inter-American Court of Human Rights; 3.4. The International Criminal Court. - 4. MAIN CHALLENGES FOR ELECTRONIC JUDICIAL COMMUNICATION: 4.1. The importance of technical aspects; 4.2. Reliability and security of the system; 4.3. The proof that the document has been filed or served and the moment it is deemed to have been filed or served; 4.4. The voluntary nature of the electronic-notification mechanisms; 4.5. The possibility of using electronic means to serve the writ commencing the proceedings; 4.6. International electronic service of documents? The example of the European procedures; 4.7. Electronic communication and international judicial cooperation. - 5. FINAL REMARKS.
\end{abstract}

\begin{abstract}
This contribution deals with the use of new technologies for the service of notice in its widest sense, which includes the filing of pleadings, the service of documents, and the notification of judicial decisions. The author analyzes some national regulations on e-service, as well as the practice at some international courts, in order to focus on the main challenges raised by the use of electronic judicial communication: 1) the way technical aspects can have repercussions over procedural safeguards and the need to count on reliable and secure systems, which can give proof that service has taken place and at what moment; 2) the possibility of a compulsory use of electronicnotification mechanisms, as well as the possibility of using them to serve the document commencing the proceedings; 3 ) the scope and requisites of a potential international electronic service of documents, under the example of some recent European procedures. The author emphasizes the idea that e-Justice is made up of tools at the service of Justice, amongst which are included electronic communications: but those tools should never dictate the development of the purpose they serve and it would also be intolerable that the legitimate exercise of rights, or that their proper legal protection, should be precluded or hindered by the deficiencies of the software tools available to the courts.
\end{abstract}

Key words: Electronic Justice (e-Justice) - Electronic service (e-Service) - Service of documents - Procedural safeguards - European Civil Procedures 


\section{E-JUSTICE AND E-SERVICE: PREVIOUS CONSIDERATIONS}

The implementation of so-called 'electronic justice' or 'e-Justice' is one of the major challenges facing the Justice system at present. In broad terms, e-Justice is understood to mean the use of 'new technologies' in the field of justice ${ }^{1}$, i.e. in the performance of the activity of the courts. The term 'new technologies' means information and communication technologies (ICT) ${ }^{2}$, which are, by definition, technologies of an electronic nature, which depend upon the use of computers, and more specifically, the internet. E-Justice therefore means the use of electronic systems in order to carry out activities that had hitherto been carried out in some other way, or in a way that was much less reliant on the said systems than is envisaged for the future.

It is important to understand that the use of electronic systems affects how an activity or institution functions, but not what it does. Thus, the term e-Justice does not refer to a different kind of Justice, or to a different Judicial Power, or to any difference in jurisdictional functioning: e-Justice is ordinary Justice, but making use of the tools that ICT provides in the organization and performance of the tasks of judicial bodies.

It is important to emphasize that e-Justice is not a field of Justice that is based on electronics and on the operation of machines running software programs, presented as an alternative to a field of Justice carried out by human beings: anything of this sort seems inconceivable to me. To be precise, it is the 'tools of e-Justice' or the 'instruments of e-Justice' that have their own separate existence, and these are or may be used by judicial bodies in the performance of their activities. But the said new technologies continue to be applied by human beings, and this fact should never be overlooked.

Therefore, the fact that judicial bodies use new tools does not mean that their nature or functions have changed, and it is clear that the use of new tools should not serve as a pretext for the introduction of any changes in their nature or functions ${ }^{3}$. The only difference is in the external configuration of the procedural acts, which are carried out electronically, but service continues to be service, even if it is carried out by e-mail, just as the evidence of a witness does not lose its essence because it is given by video link. The changes that e-Justice entails should therefore only be external and should only affect the form of the procedural acts when carried out using ICT tools. But the use of electronic systems should under no circumstances result in any of the safeguards applicable to judicial activities being prejudiced.

\footnotetext{
${ }^{1}$ Communication from the Commission to the Council, the European Parliament and the European Economic and Social Committee, "Towards a European e-Justice Strategy", 30 May 2008, COM(2008) 329 final (pp. 4-5).

${ }^{2}$ According to the definition given by the European Commission in its Communication: "The e-Justice approach uses ICT to improve citizens' access to justice and to make legal action more effective, the latter being understood as any type of activity involving the resolution of a dispute or the punishment of criminal behaviour" (p. 3). The European Parliament, in its Resolution of 18 December 2008 with recommendations to the Commission on e-Justice [2008/2125(INI)], states that "e-Justice has a broad definition including, in general, the use of electronic technologies in the field of justice". The Council, in its Multi-annual European e-Justice action plan 2009-2013 (OJ C 75, 31 March 2009), talks about "the use of information and communication technologies (ICT) in the field of justice".

${ }^{3}$ See also Taruffo, M: Orality and writing as factors of efficiency in civil litigation, in Oralidad y escritura en un proceso civil eficiente - Oral and written proceedings: Efficiency in Civil Procedure (Eds. Carpi F./Ortells, M.), Valencia, 2008, Vol. I, 202.
} 
One of the sectors where the use of ICT is envisaged as part of proceedings is that of service of notice in its widest sense, which includes the filing of pleadings, the service of documents, and the notification of judicial decisions. It is well known that from a certain point of view, proceedings are just a system of notices exchanged between different persons all playing different roles (the court and the parties in dispute): sometimes notice is served orally, in hearings, but often what the parties and the courts have to say to each other has been drafted in writing and compiled into a document, which then needs to be delivered to its addressees in accordance with legally-defined forms and procedures. The correct service of notice is necessary during the proceedings, from at least two different perspectives:

- On the one hand, the fairness of the proceedings depends on notices being served correctly: where a document served by one of the parties is not correctly received by the court, the court will deem that service has not taken place, to the (illegitimate) prejudice of the litigant, and the same unfair result can arise the other way around, where a litigant does not correctly receive a document that has been served by the court or the other party. However, experience has shown us how the right to due process of law is infringed on a daily basis as a result of the way in which notices are served ${ }^{4}$.

- On the other hand, notice must be served properly in order to avoid unnecessary delays in proceedings: inadequate internal organization within many courts, together with the difficulties and obstacles that are often put up by the addressee of the notice, mean that the service of notice is one of the elements that give rise to litigation being unduly prolonged.

The use of ICT in this field consists in taking advantage of electronic communications systems as a means to file documents and serve notices: computer programs for sending messages based on the internet or on similar telecommunications networks are used, allowing documents to be sent in electronic format from the electronic address of the sender to the electronic address of the addressee.

The main benefit of the use of electronic notices is to speed up proceedings. In addition, there can also be the advantage of reducing costs (especially postage costs, the cost of court officials, and the cost of having to rely on certain professionals whose business is to serve notices) ${ }^{5}$. Likewise, electronic service can be seen as giving rise to and being

\footnotetext{
${ }^{4}$ A quick overview on the case-law of the European Court of Human Rights offers many examples in the judgments delivered in cases like Goddi v. Italy (9 April 1984); Brozicek v. Italy (19 December 1989); Hennings v. Germany (16 December 1992); Pérez de Rada v. Spain (28 October 1998); Tsironis v. Greece (6 December 2001); Somogyi v. Italy (18 May 2004); Hermi v. Italy (28 June 2005); Strizhak v. Ukraine (8 November 2005); Examiliotis (no. 2) v. Greece (4 May 2006); Díaz Ochoa v. Spain (22 June 2006); Gregorio de Andrade v. Portugal (14 November 2006); Popova v. Russia (21 December 2006); Ern Marina Sanayi ve Ticaret A.S. v. Turkey (3 May 2007); Da Luz Domingues Ferreira v. Belgium (24 May 2007); Blandeau v. France (10 July 2008); Almeida Santos v. Portugal (6 October 2009); Société Anonyme Thaleia Karydi Axte v. Greece (5 November 2009); or Popovitsi v. Greece (14 January 2010).

${ }^{5}$ In Austria, which is without doubt the leading country in this area, it is estimated that the use of their system for the electronic filing of pleadings $(E R V)$ results in a saving equivalent to 133 jobs. Furthermore, the use of the ERV-Rückverkehr - which allows the courts to serve documents on the parties - allowed a saving of 3.6 million euros in postage in 2008, according to information supplied by the Ministry of Justice at:

http://www.justiz.gv.at/internet/html/default/2c9484852308c2a60123708554d203e7.de.html;jsessionid=2 0BD802BA25B15B66F6DD7433A013172 [03.02.2011].
} 
part of what is known as paperless procedure: in order for electronic service to take place, it is necessary for the documents to be available in electronic format (either because they have been created from scratch in such a format, or because they have been subsequently digitalized), and in turn paperless procedure can only function if notices are served electronically.

However, it would appear that when the use of ICT is encouraged in this area, not enough thought is given to overcoming the problems caused by the right to a fair trial. Electronic service is not put forward as a remedy to the problems inherent to ordinary service, given that it does not, of itself, escape them. In fact, it often seems that electronic service attracts certain safeguards that are not attached to notice served in the ordinary way. In my opinion, however, the dangers and difficulties are the same as arise for ordinary service, apparently amplified by the fact of being electronic: the truth, however, is that this factor only shifts the dangers and difficulties to another plane.

In the following pages it has been considered convenient to start with a review of how electronic service is being regulated in internal legislation and at an international level. This initial overview will allow us to identify the foreseeable problems and dangers, and how these can be averted, and we will also be able to detect the main challenges that need to be faced in the future by regulations that seek to make widespread use of efiling and e-service of notices and documents in judicial proceedings. 


\section{NATIONAL REGULATIONS CONCERNING E-FILING AND E-SERVICE OF DOCUMENTS: AN OVERVIEW}

In a significant number of countries rules have already been approved that provide a legal framework for e-filing and/or e-service of judicial documents, although these are not being applied systematically and in full in all of these countries: electronic notification is still at an experimental and introductory stage, but general implementation is gradually approaching in a fair number of the said countries.

What is stated below is not intended to be exhaustive ${ }^{6}$, given that it is based, above all, on such normative and caselaw references as it has been possible to find, with regard to a limited number of States, belonging to a variety of legal traditions: in the Germanic tradition, we will examine the situation in Austria and in Germany; in the Roman-Law tradition, France, Italy, Spain, and Brazil; in the Anglo-American tradition, the United States and England. In all cases, I set out the information that I have been able to obtain despite the limitation of not being able to have access to national reports, and with the assumption that the normative changes that occur so frequently in this area might have rendered some of the information stated out of date.

\subsection{Austria}

Austria is one of the pioneering countries in matters of e-Justice and the inclusion of ICT in the legal world ${ }^{7}$ : it made the leap towards this kind of working practice in the 1990 s, and nowadays its use would appear to be completely standard ${ }^{8}$.

\footnotetext{
6 The workflow of the Conference was envisaged to encourage the participation of all interested academics, who were invited to contribute to the drafting of a national report in response to the questionnaire I prepared at the time. Unfortunately no national report has been received in relation to this subtopic. Although it was not my intention to provide a systematic and exhaustive description of the electronic communication systems existing in each State, this situation has conditioned the structure and content of this general report: I shall restrict myself, initially, to describing the normative development that has taken place in certain States, in order to then go on to identify the main problems which, in view of the rules that have been examined, seem to arise in respect of electronic notification when it comes to the right to a fair trial.
}

For a more thorough and still recent (2007) overview, see Walker, J. / Watson, G.D.: New technologies and the civil litigation process. Common Law - General Report; Jeuland, E.: "Nouvelles technologies et procès civil. Rapport général pour les pays de droit civil"; Landoni Sosa, A.: "New information technologies in civil procedure. Synthesis report", in the context of the XIII World Congress of Procedural Law and published in Direito Processual Comparado (orgs. Pellegrini Grinover, A./ Calmon, P.), Rio de Janeiro, 2007. See also Amrani-Mekki, S.: El impacto de las nuevas tecnologías sobre la forma del proceso civil, in Oralidad y escritura en un proceso civil eficiente - Oral and written proceedings: Efficiency in Civil Procedure (Eds. Carpi, F./Ortells M.), Valencia, 2008, Vol. I.

7 See the information provided by the Austrian Ministry of Justice at: http://www.justiz.gv.at/internet/file/2c9484852308c2a601230eeed6f60127.de.0/folder_justizonline mai2008+deutsch $+\mathrm{v}+1.0$ neu.pdf [03.02.2011]

\footnotetext{
${ }^{8}$ According to the Austrian Ministry of Justice, in 2008 over 85\% of initial applications for orders for payment (Mahnklagen) and over 65\% of enforcement applications (Exekutionsanträge) were filed electronically: in total (together with the rest), 3.1 million applications were filed using this system. Also in 2008 , the courts served 3.9 million notices on the parties using electronic means. See http://www.justiz.gv.at/internet/html/default/2c9484852308c2a60123708554d203e7.de.html;jsessionid=2 0BD802BA25B15B66F6DD7433A013172 [03.02.2011].
} 
The system used for this purpose is the so-called Elektronischer Rechtsverkehr (ERV), which was set up in $1990^{9}$, and it is currently governed by the Verordnung des Bundesministers für Justiz über den Elektronischen Rechtsverkehr ${ }^{10}$ (abbreviated to Elektronischer Rechtsverkehr, ERV) ${ }^{11}$. The ERV is not an e-mail program, but rather a special system that allows data to be transmitted securely, without any need for paper, between the parties to proceedings and the court. It was initially envisaged for the parties to file documents with the court, and since 1999 it has also allowed the court to serve documents on the parties (ERV-Rückverkehr).

In order to serve notices using the ERV it is necessary to be registered as part of a special system with a closed number of users ( $\$ 7$ ERV), through which service will be effected: indeed, e-mail is expressly excluded as a forum for the exchange of data $[\S 5$ (1a) ERV]. Although in principle the system was restricted to lawyers, notaries, banks, and insurance companies, from 2000 it has been open to any interested party.

Aside from the content of the ERV Regulations, a further two provisions deserve to be highlighted:

- On the one hand, $\S 89 \mathrm{e}$ GOG, which expressly governs liability for losses caused as a result of failings in the e-filing and e-service systems, and which is attributed as a general rule to the Federation, except in cases of inevitable or unforeseeable events that are not caused by poor design or malfunction of the computerized system.

- On the other hand, $\S 112 \mathrm{ZPO}$, which allows e-filing and e-service as a possible mechanism for the lawyers of the parties to transfer documents between themselves.

\subsection{Germany}

In Germany, the regulation of electronic procedure and electronic service has been carried out by basically three Laws, which have reformed the Zivilprozessordnung $(\mathrm{ZPO})^{12}$ : the Zustellungsreformgesetz of 25 June 2001 (which came into force on 1 July 2002); the Gesetz zur Anpassung der Formvorschriften des Privatrechts und anderer Vorschriften an den modernen Rechtsgeschäftsverkehr, of 13 July 2001 (which came into force on 1 August 2002), and the Justizkommunikationsgesetz of 22 March 2005 (which came into force on 1 April 2005).

The basis for electronic service is established by $\S \S 130 \mathrm{a}$ and 130b ZPO. The former provides for all pleadings that the parties must file being drawn up in electronic format,

\footnotetext{
9 The ERV was created in collaboration by the Ministry of Justice, the Bundesrechenzentrum, the Österreichische Rechtsanwaltskammer and Telekom Austria.

${ }^{10}$ Text available at http://www.jusline.at/Elektronischer_Rechtsverkehr_(ERV).html

${ }^{11}$ The Austrian regulation of notification is scattered. General directions and some specific rules are to be found at the Zivilprozessordnung (ZPO, $\S \S 87$ a 121). However, $\S 87$ (1) ZPO refers in general terms to the Notification Act (Zustellgesetz), applying to service done by public bodies and courts http://www.bmvit.gv.at/telekommunikation/post/recht/downloads/zustellg_konsolidiert.pdf). Section 3 ( $\S 28-37 \mathrm{a})$ of the Zustellgesetz deals with electronic notification when made by public administrations,

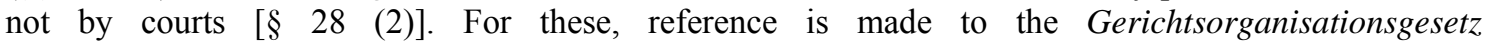
(http://www.ris.bka.gv.at/GeltendeFassung.wxe?Abfrage=Bundesnormen \&Gesetzesnummer=10000009), $\S \S 89 \mathrm{a}-891$. They don't include, however, a detailed regulation of the electronic service procedure, but only a general provision allowing any judicial notification to be made by electronic means and a reference to lower administrative rules $[\S 89 \mathrm{~b}(2) \mathrm{GOG}]$, among which the one regulating ERV.

12 http://www.gesetze-im-internet.de/zpo/
} 
with the sole condition that the said format must be suitable for the court to work with the said document and that it must feature a qualified electronic signature ${ }^{13}$. The latter ( $§ 130 \mathrm{~b}$ ZPO) recognizes the full validity of electronic documents drawn up by the court and by any other civil servants, provided that they feature a qualified electronic signature.

On the basis of these premises, the electronic notification is governed as a possible form for some communication mechanisms. Thus, the basic precept on this matter is $\S 174$ ZPO, which governs personal notification carried out by the court, which must, as a rule, be carried out with acknowledgement of receipt (Zustellung gegen Empfangsbekenntnis) and which, with a view to the use of electronic means, must distinguish as follows in accordance with the identity of the addressee:

- Where the notification is addressed to a lawyer, a notary, a Gerichtsvollzieher, a prosecutor, or to any other person who, by merit of his/her profession, ought to be considered reliable, and also when addressed to an authority, a corporation, or a publiclaw body: it may be served electronically, with acknowledgement of receipt.

- Where the notification is addressed to anyone else involved in the proceedings: service may be electronic provided that the addressee has expressly consented to being served with documents in this way.

Generically, the only requirement of the rule, in both cases, is that any document served in this way should feature an electronic signature and that the dispatch should be protected against third parties. In order to prove that notification has taken place, it is necessary to have acknowledgement of receipt with the date and the signature of the addressee, which must be returned to the court: said acknowledgement of receipt may be contained within an electronic document, but it must have a qualified electronic signature.

The electronic communication system in Germany is based on the Electronic Court and Administration Mailbox (Elektronisches Gerichts- und Verwaltungspostfach: EGVP) ${ }^{14}$ : for virtually every aspect of electronic communication between the judicial system and citizens seeking justice, it is the EGVP that is used at national level and in the Länder.

The EGVP makes possible particularly secure transmission of communications to courts, authorities and parties to proceedings. This is done via "OSCI-Transport", which corresponds to the German e-government standard and is based on the XML and SOAP standards recognised worldwide. The transmission of data on content and use is done separately, thus making the delivery of communications unequivocally transparent. Moreover, particularly secure and reliable transmission is ensured with end-to-end encryption including electronic signature of the content. The EGVP combines the advantages of e-mail (simple to operate, free formulation of communications) with the requirements of secure judicial communication (integrity of the documents transmitted, identity of the parties to the proceedings, use of qualified electronic signatures and verifiability of document servicing).

\footnotetext{
${ }^{13}$ However, the regional Governments will decide at what courts and from what moment it will be possible to use it.

${ }^{14}$ See "Member States' national projects relevant for the e-Justice portal - Reply from the German delegation", Council of the European Union - Working Party on Legal Data Processing (e-Justice), Doc. 7628/09 Add 11 JURINFO 26.
} 
For security reasons, data transmission by EGVP functions through a sort of "buffer"; the user does not communicate directly with the court, but via an "intermediary". This is a central server, on which all mailboxes are managed. No special court infrastructure is therefore required for the EGVP to operate. All the transmission technology is basically made available at a single point, which considerably reduces the technical cost for the courts. Users can obtain the necessary software free of charge and without a licence via the homepage www.egvp.de. Immediately on installation the user has his own electronic mailbox for receiving electronic documents ${ }^{15}$.

The EGVP provides access to courts "round-the-clock", as well as an immediate signed confirmation of receipt by the receiving facility of the court or authority and on-request automatic e-mail notification of receipt of communications.

Aside from what has been stated above, where personal notification should be impossible (cf. $\S 185 \mathrm{ZPO}$ ), the court may order, as a last resort, that notification be served by way of an edict (öffentliche Zustellung). Pursuant to $\S 186 \mathrm{ZPO}$, such a notification may be carried out by way of publishing the edicts on the court notice board or by way of including the edicts in an electronic court information system that is open to the public. Furthermore, the edict may also be published in the electronic version of the Bundesanzeiger ( $\$ 187 \mathrm{ZPO})$.

Finally, the service of documents between lawyers is also possible (Zustellung von Anwalt zu Anwalt) within the terms laid down at $\$ 195$ ZPO: in these cases, notification may be in electronic form and may also be proven electronically, in accordance with the provisions of $\S 174 \mathrm{ZPO}$.

\subsection{France}

In France, the regulation of electronic service was introduced into the Code de Procédure Civile by way of a Decree in $2005^{16}$, which created new Title XXI ( $\mathrm{La}$ communication par voie électronique) within Book I (which contains the common provisions applicable to all courts and to all proceedings), articles 748-1 to 748-7 $7^{17}$.

The scope allowed to the system is potentially very broad: it may be used for filing and service of any kind (article 748-1). Proof of service is provided by way of electronic acknowledgement of receipt, sent by the addressee, which must state the date, and where appropriate, the time (article 748-3 I). Furthermore, when the electronic system is used, the service of multiple copies or the return of originals ceases to be necessary (article 748-3 III).

\footnotetext{
${ }^{15}$ The EGVP has proved its worth in judicial practice and is used in supreme federal courts and in all Länder - particularly in high-frequency procedures (court registers, commercial registers and order-forpayment procedures). Since 1 January 2007, all registration processes relating to the commercial register, which has a good one million businesses on record, have been conducted via EGVP. In 2008, more than 772000 incoming and 205000 outgoing communications were transmitted to and from the participating courts and authorities. By May 2009, use had increased sharply; in April 2010, the system was transmitting over 280.000 communications. There were then more than 30.000 registered users (courts, authorities, citizens, above all lawyers and notaries).

${ }^{16}$ Through the Décret n⿳亠丷厂 2005-1678, 28 December 2005 (Journal Officiel de la République Française, 29 December 2005), in force on 1 July 2008. For a recent overview on e-Justice in France, see "Dossier - Le procès civil à l'épreuve des nouvelles technologies", Procédures, no 4, avril 2010, pp. 6-45.

${ }^{17} \mathrm{http} / / /$ www.legifrance.gouv.fr/affichCode.do?cidTexte=LEGITEXT000006070716\&dateTexte $=201005$ $\underline{19}$.
} 
The technical requirements that must be met by the system used are also established generically (article 748-6): it must ensure (i) reliability in the identification of the parties, (ii) the integrity of the documents sent, (iii) the security and confidentiality of all communications, (iv) the preservation of all transmissions made, and (v) it must allow the date of sending and the date of receipt by the addressee to be established with certainty.

However, the system is optional: the addressee must expressly consent to its use (article 748-2). But as from 1 January 2011, it has become compulsory in all appeals where representation is necessary, pursuant to the provisions of article $930-1^{18}$.

Furthermore, a series of additional safeguards have been built in: (i) where the original of a document was created in paper format, the court may order this to be produced (article 748-4); (ii) the interested party may ask to be served with any enforceable judicial decision (décision juridictionnelle revêtue de la formule exécutoire) in paper format (article 748-5); (iii) there are minimum requirements for what must be done in the event of certain 'system failures': where on the last day within a time limit for performing a certain act it is not possible to carry out e-service or e-filing for reasons beyond the control of the serving or filing party, then the time limit is extended to the following business day (article 748-7).

In order to set up the system at the level of the Tribunaux de Grande Instance, the creation of a fairly complex system has been envisaged, which involves two different computer programs -'WinCi TGI' and 'ComCi TGI'- and two private communications networks, one for the courts -Réseau privé virtuel justice, RPVJ- and another for the bar-Réseau privé virtuel avocats, RPVA- and the interaction between the two is governed by a Convention between the Ministry of Justice and the Conseil National des Barreaux, executed on 28 September $2007^{19}$, which provides for subsequent development by way of further conventions with a more reduced scope between each TGI and the specific Barreau d'avocats to which it is linked.

\subsection{Italy}

In Italy, Law 2005/80 (which ratified Legislative Decree 2005/35 of 14 March) amended various precepts of the Codice di Procedura Civile in order to allow notifications by e-mail (and also by fax). Since then, articles 133 and $134 \mathrm{CPC}$ allow the electronic notification of judgements and other judicial decisions, and article 136 CPC allows, in general terms, the performance of any kind of electronic notification ${ }^{20}$. All of these rules contain a very wide-ranging reference back to any implementing regulations that may be enacted, although the CPC itself establishes two general safeguards:

- Notification by electronic means is only possible if the defence lawyer has stated in the first document registered for the purposes of the case at what e-mail address he wishes to receive notification (arts. 133-134 CPC).

\footnotetext{
${ }^{18}$ Décret $\mathrm{n}^{\mathrm{o}} 2009-1524,9$ December 2009: the court will only accept documents sent to it by electronic means, except when it is impossible for fair reasons; and any communication or summons from the court will also be served on the parties' representatives by electronic means (Art. 930-1 I CPC).

${ }^{19} \mathrm{http}: / /$ www.heftmanavocat.com/rpva\%20doc/convention-nouvelles-technologies\%20RPVA.pdf [03.02.2011]

${ }^{20}$ http://www.altalex.com/index.php?idnot=33723
} 
- In the event that a decision, an act, or a document in electronic format is to be notified, and the addressee does not have a certified e-mail address, the notification shall be made in normal documentary format, and the court officials must preserve the electronic format for a minimum of two years. Where requested, notification shall also be carried out electronically to the address indicated by the addressee or his/her representative, or a copy of the document will be supplied in an unalterable electronic format.

The implementing provisions, paradoxically, precede the latest reform of the CPC, given that they are contained in Presidential Decree no. 123 of 13 February $2001^{21}$. This Decree envisages the creation of a system known as 'dominio giustizia', made up of the collection of hardware and software resources which serve as the basis for electronic activity in the field of Justice, and within it, the 'sistema informatico civile' is envisaged, as a part of the aforementioned system, focussing on the electronic process of civil proceedings [article 1, sections e) and f)]. The civil computerized system must be structured in such a way as to ensure the identification of the judicial office and the case, the identification of the party introducing, amending, or notifying an action, the effective receipt of the notice of the action, and the automatic authorization of the lawyer and the court officials. In fact, access to the civil computerized system is only allowed to the lawyers of the parties and the court officials (article 3).

As a general rule, all notices and service of documents must be carried out using the civil computerized system (article 2.2). However, certain notices addressed to the parties may also be carried out electronically and without using the civil computerized system (article 6): specifically, where the addressee is a lawyer, these may be addressed to the electronic address that the lawyer has notified to the professional College; in other cases, notice may be sent to the electronic address notified to the certifier of the digital signature (article 7).

Any communications and notices carried out using these channels shall be deemed to be made on the date assigned to the acknowledgement of receipt by the person responsible for serving the notice (article 8).

\subsection{Spain}

The Spanish procedural system is open to electronic communication with great clarity following the approval in 2000 of the Ley de Enjuiciamiento Civil (LEC) ${ }^{22}$. Articles 152.2.2 and 162 of the said Act allow notices to be served by electronic means, in accordance with the following provisions:

- Court offices and the parties or addressees of the items notified (lawyers and procuradores) must be in possession of the necessary electronic means. In this regard, the parties and the legal professionals participating in the process must notify the court that they are in possession of the means stated above, and of their address. Furthermore, a register (which shall be accessible electronically) is to be set up at the Ministry of Justice of the said means and of the addresses corresponding to the public authorities.

\section{1}

http://www.cnipa.gov.it/site/ files/cd Decreto\%20del\%20Presidente\%20della\%20Repubblica\%2013\%20 febbraio $\% 202001 \% 20 \mathrm{n} \% 20123$ c.pdf

22 http://noticias.juridicas.com/base_datos/Privado/11-2000.html 
- The electronic communication systems must allow the sending and receipt of pleadings and documents in which the authenticity of the communication and its content are safeguarded ${ }^{23}$, with official record of the sending and of receipt in full, and of the exact times when this happened.

In order to implement the content of the Ley de Enjuiciamiento Civil, from 2004 work began on an experimental basis on a special system of notifications, known as 'Lexnet'. Subsequently, in 2007, the Ley de Enjuiciamiento Civil was amended to provide Lexnet with a legal basis and a specific decree was approved detailing its functioning ${ }^{24}$. The Lexnet system is based on the use of an advanced e-mail program, which is only available to those who have subscribed. It ensures the authenticity of the communications, their integrity, their confidentiality, prevents them from being repudiated, and ensures they are time-stamped, thereby allowing the precise moment the message was sent and received to be recorded. In fact, all transactions using Lexnet generate an electronic receipt; an error receipt also exists which provides proof of an attempted filing or service that has failed due to a system malfunction. Currently, it is reserved for court officials, lawyers, and procuradores, but it is not yet open to private individuals. The system allows three different types of communication to be managed:

- Communication from the court to the parties: when the court needs to serve notice of a decision on a party, service is made to the Lexnet mailbox of the party's procurador or to the corresponding College of Procuradores, and service is deemed to take place at the time the procurador opens the mailbox. For this reason, Lexnet cannot be used to serve the originating writ on the defendant, given that no court advocate has been appointed at this time.

- Communication from the parties to the court: the parties may file their pleadings with the court using Lexnet, provided that they have been electronically signed, with such attached documents as may be required. Lexnet is operational 24 hours a day, every day: if filing takes place on a business day during working hours, it is deemed to take place at the time stated on the receipt generated by the system; at other times, it is deemed to take place on the first following business day at the start of the working day.

- Communication between the parties, who have to serve on one another all documents and applications filed with the court: with Lexnet, this service occurs simultaneously, with joint dispatch to the court and to the other parties. Documents sent must be in ' $\mathrm{rtf}$ ' format or some other standard form.

However, Lexnet is not the only valid system for electronic notifications. Other tools may also be used, provided that they comply with the general conditions laid down in the LEC. Thus, where a court addresses a notification to a litigant and there is proof of the correct dispatch of the communication using technical means, it shall be deemed that the communication has been lawfully carried out and that it has been fully effective

\footnotetext{
${ }^{23}$ Where the authenticity of decisions, documents, orders, or reports filed or served by electronic means can only be acknowledged or verified by way of direct examination, they may nonetheless be filed in electronic format by way of digitalized images; but they must be filed in their original paper format should any party, or the court, or the State Prosecutor's Office so request.

${ }^{24}$ Act 41/2007 (7 December 2007) and Real Decreto 84/2007, de 26 de enero, sobre implantación en la Administración de Justicia del sistema informático de telecomunicaciones Lexnet para la presentación de escritos y documentos, el traslado de copias y la realización de actos de comunicación procesal por medios telemáticos (http://www.boe.es/boe/dias/2007/02/13/pdfs/A06239-06244.pdf).
} 
once three days have elapsed without the addressee accessing its content. An exception to this rule is allowed where the addressee provides justification for not accessing the notifications system during this period. Where failure to access is due to technical reasons and these persist at the time they are to be served, the act of communication shall be carried out by way of the service of a copy of the decision. In any event, the notification shall be deemed to be validly received at the time when it is established that access to the system was possible.

Aside from all the foregoing, where other methods of communication should fail or be impossible, notice may be served by way of edicts, which must be published on the court notice board: article 164 LEC allows this form of publication to be replaced by the use of electronic formats, similar to as allowed in Germany.

\subsection{Brazil}

In Brazil, the regulation of the use of ICT in procedural law was contained in Law no. 11.419 of 19 December $2006^{25}$. This Law amends the Código de Processo Civil, article 154 of which now provides in general terms that all procedural acts may be carried out, transmitted, and stored electronically. On this basis, Law no. 11.419 regulates two different questions: the manner in which electronic communications are to be carried $\mathrm{out}^{26}$, and the performance of the proceedings in electronic format.

In general terms, the Law makes the validity of electronic procedural acts subject to the use of electronic signature and the prior accreditation of the user before the Judicial Authorities (always done in person). Once accreditation is obtained, the user will have a password to access the system that ensures the confidentiality, identification, and authenticity of all communications (article 2). Procedural acts shall be deemed to be carried out at the time they are sent to the Judicial Authority system: in the event they are subject to a time limit, they shall be deemed to be carried out in good time where the dispatch takes place prior to 24:00 hours on the day the time limit expires (article 3). Furthermore, it is declared that communications between judicial bodies ought preferentially to be carried out by electronic means (article 7).

More specifically, and in respect of electronic communications, the law envisages two different forms:

- General communication (article 4): the courts may set up an electronic 'Diário da Justiça', available on the internet, in order to publish their own judicial and administrative acts, as well as communications in general. Electronic publication in this way replaces any other notifications, except in those cases where the law requires service in person. The publication date shall be deemed to be the business day following the day on which the information is available in the Journal; and procedural time limits shall start to run from the first business day following the day on which publication was deemed to have taken place.

- Personal service (article 5): notifications where there is a specific addressee must be carried out electronically, using their own portal, to those persons who have registered on the system (thus service by ordinary e-mail shall not be sufficient). Therefore the

\footnotetext{
${ }^{25}$ Available at http://www.planalto.gov.br/ccivil 03/ Ato2004-2006/2006/Lei/L11419.htm

${ }^{26}$ A general explanation at Demócrito Reinaldo Filho, Comunicação eletrônica de atos processuais na Lei $n^{\circ}$ 11.419/06 (2007), en http://jus2.uol.com.br/doutrina/texto.asp?id=9750 [03.02.2011]
} 
acceptance of the addressee is required. Service is deemed to take place on the day on which the addressee accesses the electronic message: where this occurs on a nonbusiness day, it shall be deemed to occur on the following business day; under all circumstances, it must be carried out within ten days of the date on which the notification was sent, otherwise the notification shall be deemed to take place at that moment. In urgent cases where electronic service may prejudice the parties, or in those cases where there is evidence of an attempt to abuse the system, the procedural act must be carried out in some other way that is suitable in order for the objective to be attained. 


\subsection{United States of America}

The United States of America has been one of the first countries to introduce the use of e-Justice tools. In the scope of electronic service and filing of documents, and in the context of the federal civil procedure, it must be retained that the Federal Rules of Civil Procedure $^{27}$ regulate two different kinds of communication: on one hand, the first notification addressed to the defendant in order to inform him of the commencement of the proceedings (summons); on the other hand, any other service of documents that has to be made during the procedure.

Regarding the service of the originating summons to the defendant, there are no specific provisions allowing it to be made by electronic means: rule 4 (e)(2) FRCP states that the first service to the defendant may be done by delivering a copy of the summons and of the complaint to the individual personally, or leaving a copy of each at the individual's dwelling or usual place of abode with someone of suitable age and discretion who resides there, or delivering a copy of each to an agent authorized by appointment or by law to receive service of process.

By contrast, when it comes to the service of other documents, rule 5 FRCP allows electronic service, although the regulation is not very thorough. Apart from handing it to the addressee, leaving it at the person's office or at his dwelling or usual place of abode, mailing it to the person's last known address or leaving it with the court clerk if the person has no known address, rule 5 (b)(2)(E) allows service of a document to be made by "sending it by electronic means if the person consented in writing - in which event service is complete upon transmission, but is not effective if the serving party learns that it did not reach the person to be served".

In addition, rule 5 (d)(3) FRCP also allows the filing of documents in the court using electronic means of communication: "A court may, by local rule, allow papers to be filed, signed, or verified by electronic means that are consistent with any technical standards established by the Judicial Conference of the United States. A local rule may require electronic filing only if reasonable exceptions are allowed. A paper filed electronically in compliance with a local rule is a written paper for purposes of these rules."

There is, in a word, the possibility of e-filing and e-service of documents, with the exception of the originating summons.

\subsection{England}

The English regulation on e-service and e-filing of documents disserves a special attention, due to its thoroughness and pragmatism. The Civil Procedure Rules and their Practice Directions ${ }^{28}$ deal with electronic communication when regulating the way the parties can file documents in the courts and, also, the different ways that can be used to serve documents to the parties during the procedure.

\section{a) Filing documents by electronic means}

According to rule 5.5 CPR a practice direction may make provision for documents to be filed or sent to the court by electronic means. This general rule finds its development in

\footnotetext{
${ }^{27}$ http://www.law.cornell.edu/rules/frcp/

${ }^{28}$ http://www.justice.gov.uk/civil/procrules_fin/
} 
Practice Direction 5B, which deals with Electronic Communication and Filing of Documents, and in Practice Direction 5C, regulating the Electronic Working Scheme. Both practice directions leave room for three options: filing documents by e-mail or using two special electronic systems, the online forms service and the Electronic Working Scheme.

(i) Filing of documents by e-mail

If the Court has published an e-mail address for the filing of documents on the Court Service website (www.courtservice.gov.uk) and the document is listed on the Court Service website as a document that may be sent to or filed in that court by e-mail, then a party to a claim may send a document to the court by e-mail ${ }^{29}$. However, e-mail can not be used to take any step in a claim for which a fee is payable.

(ii) Filing of documents using the online forms service

As an alternative to e-mail, the online forms service is a service available at the forms website (www.courtservice.gov.uk): this website contains certain documents which a user may complete online and then submit electronically to a specified court. In order to be used, the court must be listed on the Court Service website as able to receive documents filed electronically via the online forms service; and the document must be available for completion on the forms website ${ }^{30}$. The online forms service can be used to take a step in a claim for which a fee is payable: the fee must be paid, using the facilities available at the online forms service.

Both the e-mail and the online forms service are ways of filing and sending a document 'electronically'. The Practice Directions have set some general provisions relating to the filing of documents electronically:

- Where a party files a document electronically, he must not send a hard copy of that document to the court.

- A document is not filed until the transmission is received by the court, whatever time it is shown to have been sent. The time of receipt of a transmission will be recorded electronically on the transmission as it is received. However, if a transmission is received after $4 \mathrm{pm}$ the transmission will be treated as received and any document attached to the transmission will be treated as filed on the next day the court office is open. The party is responsible for ensuring that the transmission or any document attached to it is filed within any relevant time limits.

- The court will normally reply by e-mail where the response is to a message transmitted electronically and the sender has provided an e-mail address.

\footnotetext{
${ }^{29}$ Regarding the technical specifications, the e-mail message must contain the name, telephone number and e-mail address of the sender and should be in plain text or rich text format rather than HTML. Correspondence and documents may be sent as either text in the body of the e-mail, or as attachments (however, documents required to be in a practice form must be sent in that form as attachments). Attachments must be sent in a format supported by the software used by the specified court to which it is sent. The length of attachments and total size of e-mail must not exceed the maximum which a particular specified court has indicated that it can accept. This information is listed on the Court Service website.

30 The online forms service will assist the user in completing a document accurately but the user is responsible for ensuring that the rules and practice directions relating to the document have been complied with. Transmission by the service does not guarantee that the document will be accepted by the specified court.
} 
- Parties are advised not to transmit electronically any correspondence or documents of a confidential or sensitive nature, as security cannot be guaranteed.

- If a document transmitted electronically requires urgent attention, the sender should contact the court by telephone.

(iii) Using the Electronic Working Scheme (Practice Direction 5C)

The Electronic Working scheme operates from 1st April 2010 (there was an Electronic Working Pilot Scheme between $1^{\text {st }}$ April 2009 and $31^{\text {st }}$ March 2010) in certain jurisdictions of England and Wales: the Admiralty, Commercial and London Mercantile Courts, the Technology and Construction Court, and the Chancery Division of the High Court at the Royal Courts of Justice, including in the case of the Chancery Division the Patents Court and the Bankruptcy and Companies courts.

The EWS makes possible that proceedings be started and all subsequent steps be taken electronically. It also permits that proceedings which have not been started electronically be continued electronically after documents in paper format have been converted to an electronic format. The EWS will operate 24 hours a day all year round, including weekends and bank holidays. This will enable claim forms to be issued and documents to be filed in electronic format out of normal court office opening hours (except for "down-time", planned or unplanned). It will receive an automated response to acknowledge receipt. Where a fee is to be paid, it may be paid by any method which Her Majesty's Courts Service may permit including any online or offline payment facility.

Persons wishing to use the EWS are required, wherever possible, to communicate with the court by means of e-mail ${ }^{31}$. When a claim form is received electronically at the address provided by the court, the claim form will be issued, sealed and returned to the claimant for service: it is then a party's responsibility to print and serve the claim form, unless the party or parties to be served have agreed to accept service by email or other electronic means. The court will accept receipt of claim forms filed through EWS out of normal court office opening hours: claim forms received by the court up to midnight will bear the date they are received as the issue date.

In order to grant security, Her Majesty's Courts Service will take such measures as it thinks fit to ensure the security of steps taken or information communicated or stored electronically. It may provide such method of encryption to promote security of e-mail communications as may be deemed appropriate.

\section{b) Serving documents by electronic means}

Rule 6.3 CPR establishes the methods that can be used to serve a claim form: among them, rule 6.3 (1)(d) allows the use of "other means of electronic communication in accordance with Practice Direction 6A". For the service of documents other than the claim form rule 6.20 (1)(d) allows also the use of "other means of electronic communication in accordance with Practice Direction 6A".

\footnotetext{
${ }^{31}$ EWS users must ensure that all forms, documents, schedules and other attachments filed at court are in PDF format. They also must use the PDF forms which have been created by Her Majesty's Courts Service specifically for Electronic Working. If they wish to file any document which has not been created specifically for Electronic Working, before filing that document they must convert the document to PDF format and attach the document to the multi purpose form for that case which has been created specifically for Electronic Working.
} 
In both situations -service of claim form, service of other documents-, rule 6.23 (6) states that where a party indicates that she will accept service by electronic means other than fax, the e-mail address or electronic identification given by that party will be deemed to be at the address for service.

Practice Direction 6A (paras 4.1 and 4.2) develops the general provisions of rule 6 CPR. As a general condition, where a document is to be served by electronic means, the party who is to be served or the solicitor acting for that party must previously have indicated in writing to the party serving that the party to be served or the solicitor is willing to accept service by electronic means and the e-mail address or other electronic identification to which it must be sent. For those purposes, the following are to be taken as sufficient written indications: an e-mail address set out on the writing paper of the solicitor acting for the party to be served but only where it is stated that the e-mail address may be used for service; or an e-mail address or electronic identification set out on a statement of case or a response to a claim filed with the court.

In addition, where a party intends to serve a document by electronic means that party must first ask the party who is to be served whether there are any limitations to the recipient's agreement to accept service by such means (for example, the format in which documents are to be sent and the maximum size of attachments that may be received). Where a document is served by electronic means, the party serving the document need not in addition send or deliver a hard copy.

The use of electronic means of communication should also be possible, according to rule $6.11 \mathrm{CPR}$, if it is the contractually agreed method: a contract contains a term providing that, in the event of a claim being started in relation to the contract, the claim form may be served by a method or at a place specified in the contract.

\subsection{Other European countries}

In May 2007 the Council of the European Union published the "Study of the situation regarding the use of information and communications technology (ICT) in Member States' judicial systems with particular attention to eJustice" ${ }^{\$ 2}$, carried out by the Europäischen EDV-Akademie des Rechts GmbH (EEAR) [European IT Academy of Law], Merzig, Germany. As a general description of the situation, following is stated: "In recent years many Member States have made it possible under their court rules of procedure for documents to be transmitted in electronic form to courts and public prosecutors. Other Member States plan to introduce such a system in the near future. Electronic communication already applies, in particular in civil proceedings and summary proceedings. Overall, however, the level of use of electronic communication is not very high, although the limited experience gained thus far is described as positive across the board." A few months later (july-september 2007) all Member States sent to the Council a description of the use of information and communication technology in its judicial system. Although the information might not be as fresh as it would be desirable, it can help to get an idea of the situation in European countries other than those studied with further attention in this report. Those are the general answers to the topic

\footnotetext{
${ }^{32}$ Doc. 9083/07 JURINFO 13 and Doc. 9573/07 JURINFO 17). The contents of the study can be read at http://register.consilium.europa.eu/pdf/en/07/st09/st09083.en07.pdf [03.02.2011] (main study) and at http://register.consilium.europa.eu/pdf/en/07/st09/st09573.en07.pdf [03.02.2011] (Study Part II: Comparative Analysis).
} 


\section{"Electronic communication with parties involved in proceedings" furnished by each} State:

Denmark: "In Danish judicial proceedings lawyers and other parties involved cannot yet send documents to courts and public prosecutor's offices electronically. Appropriate legislative rules are planned for all types of proceedings, however. The courts and public prosecutor's offices are set to be able to send documents back electronically to parties involved in proceedings under 2004 rules already established but not yet in force. There are no technical standards for electronic communication with parties involved in proceedings. The authenticity and integrity of documents transmitted electronically are guaranteed only in data communication with public prosecutor's offices using advanced electronic signature procedures." (Doc. 9083/07 Add 3 JURINFO 13)

http://register.consilium.europa.eu/pdf/en/07/st09/st09083-ad03.en07.pdf

Bulgaria: "Parties involved in proceedings before Bulgarian courts have hitherto been unable to submit documents electronically, although there are plans to put the corresponding arrangements in place for civil and enforcement proceedings and the relevant technical systems have already been partially realised. The same applies to the dispatch of electronic documents by Bulgarian courts and judicial authorities. Here, too, technical systems have already been put in place for civil proceedings in general and for debt enforcement and enforcement proceedings in particular, but there is still no legal basis for their use. Consequently, nor have any technical standards been laid down by law for electronic communication between the courts and outsiders, although there are plans to establish such standards. The advanced electronic signature within the meaning of Article 2(2) of the Directive on electronic signatures may be used in Bulgaria as a means of authentication." (Doc. 9083/07 Add 2 JURINFO 13)

http://register.consilium.europa.eu/pdf/en/07/st09/st09083-ad02.en07.pdf

Belgium: "In some Belgian court procedures, lawyers and other participants in proceedings can send documents electronically to courts and public prosecutors' offices. The legal and technical conditions for this have existed since 2006, but have not yet been implemented. Courts and public prosecutors will also be able to return documents electronically to persons involved in proceedings under legislation already framed but still to be implemented. There are no technical standards for electronic communication with persons involved in proceedings. The authenticity and integrity of electronically transmitted documents is ensured by simple and advanced electronic signatures." (Doc. 9083/07 Add 1 JURINFO 13)

http://register.consilium.europa.eu/pdf/en/07/st09/st09083-ad01.en07.pdf

Estonia: "Since recently, the filing of documents in electronic form has been permissible for all types of proceedings in Estonia and the corresponding systems have been implemented. Although it is not yet used in the majority of cases, in some types of proceedings it is in widespread use. A similar situation applies to the transmission of documents by courts, although this is less widely used than electronic filing. Technical standards exist for that purpose and binding rules are planned. At present, structured documents are communicated via the Internet. Where authentication is required, this is achieved by means of the qualified signature within the meaning of Article 5(1) of the Signatures Directive." (Doc. 9083/07 Add 5 JURINFO 13)

http://register.consilium.europa.eu/pdf/en/07/st09/st09083-ad05.en07.pdf

Ireland: "For a short time now, the electronic filing of documents by outsiders via an internet portal has been possible in some cases in respect of Irish social court proceedings, and this system is already in frequent use. Where documents are filed electronically, the data are transmitted in structured form. In other proceedings, electronic filing of documents is not yet possible, though there are plans to introduce such a system for general civil-law actions and debt enforcement and enforcement proceedings. There is no provision for the electronic transmission of documents by the courts. Consequently, no standards are laid down in that connection in Ireland." (Doc. 9083/07 Add 9 JURINFO 13)

http://register.consilium.europa.eu/pdf/en/07/st09/st09083-ad09.en07.pdf 
Finland: "Since the middle of the 1990s it has been possible to file documents in electronic form in Finnish civil law proceedings and many are indeed filed in this way. Since 2003 this has also been possible for administrative and other types of proceedings, but less use has been made of this option in certain cases. The situation regarding the transmission of documents by the courts is very similar; applications initiating proceedings may not, however, be transmitted electronically. The primary technical tool is secure e-mail. In addition, Finland has standards on data file formats and the structure of documents for transmission to the courts, although these standards are not mandatory. If an authentification is required, a simple electronic signature within the meaning of Article 2, point 1 of the Signatures Directive is provided." (Doc. 9083/07 Add 6 JURINFO 13)

http://register.consilium.europa.eu/pdf/en/07/st09/st09083-ad06.en07.pdf

Greece: "In some court proceedings in Greece lawyers and other parties involved can send documents electronically to courts and public prosecutors' offices. In some proceedings courts and public prosecutors' offices can also send back documents electronically to the parties involved. However, these possibilities are used only infrequently. There are technical standards for electronic communication with parties involved in the proceedings but there is no legal obligation to observe them. An electronic signature to protect the authenticity and integrity of documents sent electronically must first be introduced". (Doc. 9083/07 Add 8 JURINFO 13)

http://register.consilium.europa.eu/pdf/en/07/st09/st09083-ad08.en07.pdf

Lithuania: "In Lithuanian legal proceedings, lawyers and other parties involved in proceedings may not file documents with courts and public prosecutors in electronic form, nor are any corresponding legislative rules planned. Electronic signatures are not used." (Doc. 9083/07 Add 12 JURINFO 13)

http://register.consilium.europa.eu/pdf/en/07/st09/st09083-ad12.en07.pdf

Netherlands: "At present there are no legal proceedings in the Netherlands in respect of which it is legally permissible for lawyers and other parties involved in proceedings to file documents with courts and public prosecutors in electronic form. Rules which would make this possible in the future are planned for only a few types of proceedings. In that connection, experiments are being conducted to test the use of technical solutions. As a rule, courts and public prosecutors may not transmit documents to persons involved in proceedings by electronic means. No legal amendments are planned in that respect. For certain proceedings, however, judgments are sent automatically and electronically to various bodies outside the judicial system. Electronic standards are applied to the electronic communication of judgments." (Doc. 9083/07 Add 14 JURINFO 13)

http://register.consilium.europa.eu/pdf/en/07/st09/st09083-ad14.en07.pdf

Latvia: "The electronic filing of documents by public prosecutors and other parties involved in the proceedings is currently legally permissible and technically feasible in criminal proceedings only. Very little use is made of this possibility. The same applies to the submission of documents by courts and public prosecutors. This is also for the moment only possible in criminal proceedings. Basically only those offices in the Latvian judicial system with sufficient electronic signatures may be involved in electronic communication. Family and inheritance matters are excluded by law from the electronic transmission of documents. Certain document containing personal data may only be communicated in electronic format using certain procedures. In Latvia there are technical standards for electronic communication with courts, but these have not yet been established by law. However, a uniform court information system is currently being developed on the basis of international standards. Authentification is provided for using a qualified electronic signature within the meaning of Article 5(1) of the Signatures Directive.” (Doc. 9083/07 Add 11 JURINFO 13) http://register.consilium.europa.eu/pdf/en/07/st09/st09083-ad11.en07.pdf

Luxembourg: "At present there are no legal proceedings in Luxembourg in respect of which the electronic filing or electronic dispatch of documents by the judicial system is legally 
permissible or implemented, nor do any technical standards exist yet in that connection." (Doc. 9083/07 Add 13 JURINFO 13)

http://register.consilium.europa.eu/pdf/en/07/st09/st09083-ad13.en07.pdf

Sweden: "In some Swedish legal proceedings, lawyers and other parties involved in proceedings may file documents with courts and public prosecutors in electronic form; however, this does not apply to documents which must be signed. Courts and public prosecutors may transmit documents to persons involved in proceedings by electronic means, but as a complement to and never in place of physical documents. No electronic standards exist for electronic communication with persons involved in proceedings. No electronic signatures exist to protect the authenticity and integrity of electronically transmitted documents." (Doc. 9083/07 Add 19 JURINFO 13)

http://register.consilium.europa.eu/pdf/en/07/st09/st09083-ad19.en07.pdf

Slovakia: "In many Slovakian legal proceedings, lawyers and other parties involved in proceedings may file documents with courts and public prosecutors' offices in electronic form. Courts and public prosecutors' offices may send documents back to persons involved in proceedings in electronic form. However, they make very little use of either option, despite the fact that they have been technically implemented, at least in part. There are mandatory technical standards for electronic communication with persons involved in proceedings. No electronic signatures exist as yet to protect the authenticity and integrity of electronically transmitted documents. However, the law on a certified electronic signature is to enter into force in mid-2007." (Doc. 9083/07 Add 20 JURINFO 13)

http://register.consilium.europa.eu/pdf/en/07/st09/st09083-ad20.en07.pdf

Cyprus: "In Cypriot legal proceedings, lawyers and other persons involved may not file documents electronically with courts or public prosecutor's offices. Nor may courts or public prosecutors' offices send back documents electronically to persons involved in proceedings." (Doc. 9083/07 Add 26 JURINFO 13)

http://register.consilium.europa.eu/pdf/en/07/st09/st09083-ad26.en07.pdf

Poland: "In some Polish legal proceedings, lawyers and other parties involved in proceedings may file documents with courts and public prosecutors in electronic form. In some proceedings courts and public prosecutors can also return documents electronically to persons involved in proceedings. No technical standards exist for electronic communication with persons involved in proceedings. The authenticity and integrity of electronically transmitted documents are ensured by advanced electronic signature." (Doc. 9083/07 Add 16 JURINFO 13)

http://register.consilium.europa.eu/pdf/en/07/st09/st09083-ad16.en07.pdf

Romania: "In Romanian legal proceedings, lawyers and other parties involved in proceedings are not yet able to file documents with courts and public prosecutors in electronic form, nor does the judicial system currently transmit documents by electronic means." (Doc. 9083/07 Add 18 JURINFO 13)

http://register.consilium.europa.eu/pdf/en/07/st09/st09083-ad18.en07.pdf

Czech Republic: "In some Czech legal proceedings, lawyers and other parties may file documents with courts and public prosecutors in electronic form. Courts and public prosecutors may return documents to persons involved in proceedings by electronic means. However, neither option is used very much, despite being technically feasible. No technical standards exist for electronic communication with persons involved in proceedings. The authenticity and integrity of electronically transmitted documents are guaranteed by simple electronic signature." (Doc. 9083/07 Add 23 JURINFO 13)

http://register.consilium.europa.eu/pdf/en/07/st09/st09083-ad23.en07.pdf

Hungary: "There are currently no Hungarian court proceedings which allow lawyers or other parties involved in the proceedings to file documents electronically with courts and public prosecutors' offices. Likewise, courts and public prosecutors' offices for their part have no legal possibility of sending documents back electronically to parties involved in the 
proceedings. Both options are planned for most types of proceedings, and appropriate laws and rules are under preparation. In order to protect the authenticity and integrity of electronically transmitted documents, Hungary uses both advanced and qualified electronic signature within the meaning of the Signatures Directive." (Doc. 9083/07 Add 24 JURINFO 13)

http://register.consilium.europa.eu/pdf/en/07/st09/st09083-ad24.en07.pdf

Slovenia: "Lawyers and other parties involved in proceedings may file documents with courts and public prosecutors in electronic form in debt enforcement and other enforcement proceedings under the Slovenian systems of civil and administrative law; rules are planned for all other types of proceedings. A similar situation obtains as regards judicial authorities sending out procedural documents electronically; in administrative court proceedings this is already permitted and feasible; for all other proceedings it is planned. Technical standards exist for the transfer and structuring of electronic data, but are not specifically laid down. XML and secure e-mail are relied upon in the main. Where authentication is required in connection with electronic communication, a qualified electronic signature within the meaning of Article 5(1) of the Signatures Directive is available, as well as the Justice Ministry's own certificates. PGP encryption is also used." (Doc 9083/07 Add 21 JURINFO 13)

http://register.consilium.europa.eu/pdf/en/07/st09/st09083-ad21.en07.pdf

Portugal: "In many Portuguese legal proceedings, lawyers and other parties involved in proceedings may file documents with courts and public prosecutors in electronic form. The legal and technical framework conditions have been in place since 2001 and this type of communication is now well-accepted. Courts and public prosecutors can also return documents electronically to persons involved in proceedings and this option is widely used. No technical standards exist for electronic communication with persons involved in proceedings. The authenticity and integrity of electronically transmitted documents are ensured by advanced electronic signature.” (Doc. 9083/07 Add 17 JURINFO 13) http://register.consilium.europa.eu/pdf/en/07/st09/st09083-ad17.en07.pdf

A short description of the situation in Norway (non EU-Member State) can be found at the Presentation on "The Use of Information Technology in the Norwegian Justice Sector", directed to the Working Party on Legal Data Processing (e-Justice) of the Council (Doc. 14485/09 JURINFO 120).

More recently, the Working Party on Legal Data Processing (e-Justice) of the Council of the European Union has decided to examine the Member States's national projects on e-Justice ${ }^{33}$ and the topic of electronic service of documents in greater detail ${ }^{34}:$ it is clear that it will be an area in which further developments are to be awaited.

The main general conclusions on our topic are the following:

"c) Electronic submission of writs of summons and other documents

11 Electronic submission of writs of summons and other documents concerns the transmission of legally relevant documents from the parties to the courts by electronic means. Authentication of the sender is therefore an important issue in order to avoid abuse.

12 In some Member States such electronic submission of documents is already possible. However, in some cases this applies only to lawyers, notaries and other persons especially registered for this purpose (DE, AT). While some systems use qualified electronic signatures for authentication (DE, EE), in some systems other methods such as a simple username/password combination apply (AT, UK).

\footnotetext{
${ }^{33}$ See Doc. 13759/09 JURINFO 112 (13 October 2009).

${ }^{34}$ See Doc. 7355/10 EJUSTICE 28 JUSTCIV 43 (12 March 2010), including a list of questions prepared by the Presidency to structure the discussions (http://register.consilium.europa.eu/pdf/en/10/st07/st07355.en10.pdf). Some countries have already submitted their answers (Spain, Italy and Poland).
} 
13 In some Member States the electronic transmission of written submissions is obligatory for lawyers, subject in some cases to technical constraints on the lawyer's side (AT).

14 Subject to the requirement of electronic signature, online application open to the general public is available in some Member States for certain special procedures (DE: payment orders, forms for other applications under construction; EE: payment orders, online applications are possible to most registers and administrative authorities for all citizens and a special e-Notary environment has been created for notaries; FR payment orders, administrative applications and guardians, all under construction; PL: pledge register, obligatory; UK: county court money claims and possession claims), and under construction for all cases in other Member States (EE).

15 In other Member States there are projects regarding the electronic transmission of applications (DK, HU, MT) or electronic communication between lawyers and the registries of the courts (FR).

\section{d) Electronic service of documents}

16 Electronic service of documents concerns judicial and extrajudicial documents sent from the courts or the bailiffs to the parties. It should be borne in mind that in some Member States service of documents is effected by a specific profession, the bailiffs, whereas in other Member States documents are notified to the parties directly by the courts. Nevertheless, some practical problems encountered with efforts to digitalise service of documents remain similar, regardless of whether the service of documents is effected by the courts or by the bailiffs and regardless of whether the document to be served is e.g. a writ of summons to be served on the defendant, or a judgment: In order to take legal effect, service will in most cases require that the addressee has at least the opportunity to receive the document and that the court is informed about this fact by an acknowledgment of receipt.

17 In some Member States documents can already be served electronically with the electronic service having the same legal effect as service of documents in paper form (AT; IT: only some courts so far). Other Member States have projects running to this effect (HU). In most cases this is, however, restricted to lawyers, notaries or other persons who have expressly agreed to it, or to persons who have made use of the possibility of electronic transmission of applications (in the case concerned or in other cases). Sometimes, certain types of documents are excluded from the option of electronic service. From these restrictions it appears that in most Member States it is possible only in exceptional cases to serve documents instituting proceedings electronically.

18 Most systems create a return receipt automatically, some as soon as the document has reached the mailbox (IT, AT), some only when the document is actually downloaded/opened actively by the recipient (HU), the latter providing for a fiction of receipt some days after the document has reached the mailbox. An electronically signed acknowledgment of receipt is possible in some systems (HU).

19 Several other Member States have projects on the electronic service of documents. In some Member States (IT, HU) it will be obligatory in certain cases to sign up to the system for electronic service, so that as a result any service in these cases can be effected electronically."

\section{E-SERVICE AT INTERNATIONAL COURTS}

Just like at a national level, the tools of e-Justice are gradually finding their place in international courts. There are indeed some rules allowing the use of electronic means to file documents and to make service at least in procedures before the Court of Justice of the European Union, the European Court of Human Rights, the Inter-American Court of Human Rights and the International Criminal Court. Proceedings before those courts are quite special and the service of documents is rarely threatened by the same dangers existing in national procedures. That is probably the reason why the rules dealing with this matter are little thorough. However, international regulations show a general concern with the same questions that are source of worries at a national level. 


\subsection{The Court of Justice of the European Union}

The Rules of Procedure of the Court of Justice of the European Union ${ }^{35}$ include some provisions regarding e-filing of documents addressed to the Court and e-service of documents addressed to the parties.

\section{a) E-Filing}

According to Article 37 (6) of the Rules, pleadings to the Court can be filed by "other technical means of communication available to the Court", which includes e-mail ${ }^{36}$. Where transmission is by electronic mail, only a scanned copy of the signed original will be accepted ${ }^{37}$ : an ordinary electronic file or one bearing an electronic signature or a computer-generated facsimile signature will not be treated as complying with the rules.

In such case, the date on which the copy of the signed original of the pleading is received at the Registry by telefax or email shall be deemed to be the date of lodgment for the purposes of compliance with the time-limits for taking steps in proceedings, provided that the signed original of the pleading, accompanied by the annexes and copies, is lodged at the Registry no later than 10 days thereafter ${ }^{38}$. E-filing or elodgment of documents, hence, is only a way to accelerate the delays and to comply with time-limits, but doesn't substitute traditional filing of the original paper documents.

\section{b) E-Service}

Every lawyer or agent acting before the Court shall state an address for service in the place where the Court has its seat and the name of the person who is authorised and has expressed willingness to accept service. However, Article 38 (2) allows the lawyer or agent to state that they agree that service is to be effected on him by telefax or other technical means of communication: the statement must specify the electronic mail address to which the Registry may send that party documents to be served. The recipient's computer must be equipped with suitable software (for example, Acrobat or Readiris 7 Pro) for reception and display of communications from the Registry, which will be transmitted in PDF format.

In such cases, any procedural document other than a judgment or order of the Court may be served to the addressee by the transmission of a copy of the document by such means and shall be deemed to have been duly served when such means are used [Article 79 (2)]. However, where for technical reasons or on account of the nature or length of the

\footnotetext{
${ }^{35}$ http://curia.europa.eu/jcms/upload/docs/application/pdf/2010-04/rp.en.pdf [03.02.2011]

${ }^{36}$ According to the Practice Directions relating to direct actions and appeals - Use of technical means of communication, a copy of the signed original of a procedural document may be transmitted to the Registry as an attachment to an electronic mail to the email address ecj.registry@curia.europa.eu (http://curia.europa.eu/jcms/upload/docs/application/pdf/2009-02/ins prat2 2009-02-09 16-1531 502.pdf).

37 According to the same Practice Directions, documents should be scanned at a resolution of 300 DPI and, wherever possible, in PDF format (images plus text), using Acrobat or Readiris 7 Pro software.

38 The Practice Directions also state that the signed original must be sent without delay, immediately after the despatch of the copy by e-mail, without any corrections or amendments, even of a minor nature. In the event of any discrepancy between the signed original and the copy previously lodged, only the date of lodgment of the signed original will be taken into consideration.
} 
document transmission by e-mail is not feasible, the document shall be served by traditional means 39 .

\subsection{The European Court of Human Rights}

For procedures held before the European Court of Human Rights there is a Practice Direction concerning "Secured electronic filing", In fact, the ECHR has set out a system of secured electronic filing, which can be used voluntarily by the Governments of the Contracting States. The Governments which have opted for that system shall send all their written communications with the Court by uploading them on the secured Internet site set up for that purpose and shall accept written communications sent to them by the Registry of the Court by downloading them from that site ${ }^{41}$. In order to do so, the Government shall possess the necessary technical equipment and follow the user manual sent to them by the Court's Registry.

Regarding format, it is foreseen that documents filed electronically shall be in PDF format, preferably in searchable PDF. Signed documents to be filed electronically shall be generated by scanning the original paper copy.

As to the relevant date with regard to time limits, the date on which the Government has successfully uploaded a document on the secured site shall be considered as the date of dispatch. To facilitate keeping track of the correspondence exchanged, every day shortly before midnight the secured server generates automatically an electronic mail message listing the documents that have been filed electronically within the past 24 hours.

The secured electronic site shall not permit the modification, replacement or deletion of an uploaded document. If the need arises for the Government to modify a document they have uploaded, they shall create a new document named differently (for example, by adding the word "modified" in the document name). Where the Government has filed more than one version of the same document, only the document filed in time shall be taken into consideration. Where more than one version has been filed in time, the latest version shall be taken into consideration, unless the President of the Chamber decides otherwise.

\subsection{The Inter-American Court of Human Rights}

The Rules of Procedure of the Inter-American Court of Human Rights ${ }^{42}$ contain also some general provisions regarding electronic filing and transmission of documents.

\footnotetext{
${ }^{39}$ See also the Notes for the guidance of Counsel in written and oral proceedings before the Court of Justice of the European Communities (February 2009: http://curia.europa.eu/jcms/upload/docs/application/pdf/2008-09/txt9_2008-09-25 17-37-52_275.pdf) [03.02.2011] and the Practice Directions relating to direct actions and appeals - Use of technical means of communication.

40 Issued by the President of the Court on 22 September 2008 (http://www.echr.coe.int/NR/rdonlyres/C3F78149-F39D-48E9-B34899C86FFDD273/0/SecuredDocumentsDecember2008.pdf) [03.02.2011].

41 There are only a few exceptions: a) All written communications in relation to a request for interim measures shall be sent simultaneously through the secured site and by fax; b) Attachments, such as plans, manuals, etc. which may not be comprehensively viewed in an electronic format may be filed by post; c) The Court's Registry may request that a paper document or attachment be submitted by post.

42 Approved by the Court during its LXXXV Regular Period of Sessions in November 2009 (http://www.corteidh.or.cr/reglamento.cfm).
} 


\section{a) E-filing of documents}

According to Article 28, all briefs addressed to the Court may be presented by electronic mail. Every brief must be signed, in order to ensure authenticity. If it is transmitted to the Court by electronic means and has not been subscribed, the original documents must be received by the Court within a term of 21 days from the expiration of the deadline established for the submission of that brief.

\section{b) E-service of documents}

E-service is foreseen by Article 33 in very general terms: it allows the Court to transmit briefs, annexes, orders, judgments, advisory opinions, and other communications submitted to it by electronic means with adequate guarantees of security.

\subsection{The International Criminal Court}

According to the Regulations of the Court ${ }^{43}$ the procedure before the International Criminal Court should be managed taking the most possible advantage of electronic means. Regulation 26 states that the Court shall establish a reliable, secure, efficient electronic system to support its daily judicial and operational management and its proceedings. The system will ensure authenticity, accuracy, confidentiality and preservation of judicial records and material.

\section{a) E-Filing}

All documents, decisions and orders shall, whenever possible, be submitted in electronic version for registration by the Registry. The electronic version of filings shall be authoritative [Regulation 26 (3)].

\section{b) E-Service}

In order to be served of any document registered by the Registry or any decision of the court, all participants shall provide to the Registry an electronic, facsimile or postal contact address for notification of documents (preferably in The Hague). If the participant provides an e-mail address, he will be notified by this means ${ }^{44}$ and he will be deemed notified, informed of or to have had communicated to him, a document, decision or order on the day it is effectively sent from the Court by the Registry. Such date shall be written on the notification form to be appended to all copies of the document, decision or order, as relevant [Regulation 31 (1) and (2)].

As an alternative, a participant represented by counsel shall be deemed notified when his counsel has been notified of a document, decision or order at the electronic, facsimile or postal address which that counsel has indicated to the Registry [Regulation $32(3)]$.

\footnotetext{
43 Adopted by the judges of the Court on 26 May 2004, Fifth Plenary Session, The Hague, 17- 28 May 2004 [Official documents of the International Criminal Court, ICC-BD/01-01-04] (http://www.icccpi.int/NR/rdonlyres/B920AD62-DF49-4010-8907E0D8CC61EBA4/277527/Regulations_of the_Court_170604EN.pdf) [03.02.2011]

44 E-mail notification is not possible when personal service is required, and this happens with the following documents: (a) Warrants of arrest; (b) Summonses to appear; (c) Documents containing the charges; and (d) Such other documents, decisions or orders ordered by the Chamber to be notified by way of personal service.
} 


\section{MAIN CHALLENGES FOR ELECTRONIC JUDICIAL COMMUNICATION}

Any regulation of the electronic service of documents benefits from the fact that electronic communications have become standard practice in most business and contractual relationships: for this reason it is being introduced quite naturally into legal proceedings, with little scope for resistance from members of the legal profession. It is not area in which one can say that there is any 'fear of the unknown'.

The legal overview, however, is very heterogeneous, as shown in the precedent pages. Most of the States have made legal reforms in a pretty short period of time in order to introduce new rules to make possible the e-filing and the e-service of documents. In addition, the reforms have been quite frequently carried out in two steps: legal norms with general contents, followed by much more detailed regulations of a lower rank. It is also quite striking to realize how, despite the diversity, there is a common core of questions which constantly catch the attention of lawmakers -even if with different degrees of concern-.

\subsection{The importance of technical aspects}

Legislators are clearly concerned about the technical aspects associated with electronic service. Some legislators, for example, are careful to clarify whether or not ordinary systems such as e-mail may be used, or whether, in contrast, it is preferable to use special systems, and on the same subject, whether the electronic communication systems are to be part of the internet, or whether, in contrast, different communications networks are to be used (Austria with its Elektronischer Rechtsverkehr, England with its Electronic Working Scheme, Spain with its Lexnet, Italy with its sistema informatico civile).

These appear to be decisions of a strictly technical nature, given that they are driven by efficiency, costs, and security criteria, which are regarded differently in each country. However, these may also have repercussions on the right to a fair trial: an electronic service system can only be implemented and made widespread if it is ensured that all interested parties or all parties under a legal duty to use it can have access to it, such that any technical options that do not have the potential to become universal ought to be rejected.

Some jurisdictions also contain much more detailed requirements, relating to the format or the size of the files that may be sent electronically, which once again may have an effect on the right to a fair trial (this may be clearly seen in English and in Spanish legislation, as well as in the rules of the European Court of Justice and the European Court of Human Rights). There is no doubt that the correct functioning of the computer systems may require all files to have specific standardized formats (such as RTF in Spain or PDF in England and in the European Court of Justice): however, these must be formats that are easy to use and that are universally accessible, in order not to prejudice access to justice. With regard to the requirements on file sizes, these may be technically justifiable, in the sense that the systems will not handle files that are too large. However, on this point the dangers to the right to a fair trial are more significant, because the size and weight of files do not always depend on the will of the parties: therefore any technical restrictions on capacity within the systems should not lead to restrictions on the rights of the parties to file pleadings and adduce evidence. For this reason, technical formulas ought to be found that allow large files to be sent 
electronically, or an alternative to electronic filing and service ought to be allowed, despite being defined as compulsory.

\subsection{Reliability and security of the system}

A system of electronic legal notification must be designed taking into account the tension that exists between competing interests. On the one hand, the efficiency and speed of the system must be considered: this is something which is expected, by definition, of all computerized systems. Now then, there are certain requirements regarding security and reliability of the system which must also be respected and which are in relation to the generic notion of 'procedural safeguard'. In this regard, the system must be capable of ensuring the following points:

- Authenticity, by way of mechanisms that verify the identity of the issuer.

- Integrity, such that it is possible to prove what has been sent and that this has not been altered after being sent.

- Non repudiation, i.e. proof that the notice has been served, such that the issuer cannot deny that it has been sent, and the addressee cannot deny that it has been received.

- Confidentiality, such that only the addressee may have access to the content of the information.

- Timestamping, so that it is possible to verify the exact time a message was sent and received.

The above conditions must be met if the system is to be reliable and if it is to respect the rights of all those involved.

The analyzed legal systems deal with all or most of those questions and state in general terms that the electronic systems of service need to meet the technical requirements assuring their effectiveness. It has to be noticed, anyway, that they are not facing really new requirements, since they are common to every system of service or communication: the mentioned conditions must also be met when serving documents by "traditional" means. The difference lays in the origin of the problems and of the possible obstacles to comply with those requirements. When using traditional means, the system lays on the reliability given to the work of certain persons: specially court officers, huissiers de justice, procuradores or postmen.

In electronic systems, instead, there must be a double source of trust: there is of course a need to have trust in the persons that operate the systems; but there is an additional need that the electronic system itself is reliable: in a word, within the scope of e-Justice, in order to avoid errors, and where appropriate, correct them, one must have faith not only un persons, but also in computers; the problem is that legal staff and legal professionals, as a rule, do not have advanced computer skills - nor is there any reason why they should - and they feel uncomfortable when they are obliged to trust computer specialists. This is the reason why, at this point, national procedural laws can only include general provisions and are based on the assumption that any system introduced according to their rules will comply with the requirements set in the law: this can be easily seen when law relates to electronic signature and requires from it a certain degree of security.

In any case, there is a clear paradox in the high level of suspicion that is aroused by electronic means of service when compared to personal or traditional means of service: 
situations in which a service carried out by a person is defective are quite frequent and many legal systems allow service to be carried out by certain non electronic means that are merely fictive and provide no proof that notice has arrived to the addressee (like service by publishing the document at an official journal or service by deposit of the document in the addressee's mailbox).

To put it briefly, when it comes to assessing the suitability of using electronic systems as a tool for serving notices in judicial proceedings, it is best to avoid extremes. It is obvious that electronic communications can be subject to poor performance, errors, and system breakdowns that are difficult to explain and fix, or even abuse, as may be seen in a wide variety of electronic interaction. It is also true that people make mistakes and the legal systems of all countries are full of examples of notices being served incorrectly by people using traditional methods.

For this reason, legislators must also foresee how people will react in situations where things go wrong for technical reasons, and take into account the peculiarities of electronic systems when it comes to regulating their consequences and allowing for possible remedies. In that sense, some legislations consider that system's failures can happen and have established some safeguards for the litigants (as seen in Spain, France, Brazil, England or before the Court of Justice of the European Union). Austria has gone a step beyond and has set the general rule of public responsibility in case of malfunction of those systems.

Besides, the need to strengthen the trust in electronic service systems entails the additional need to turn to companies that carry out the managing ant the compliance of the system's reliability and security requirements, and this will certainly involve additional costs: the set-up and maintenance of secure computerized systems through which to undertake the electronic service of documents has an economic cost.

\subsection{The proof that the document has been filed or served and the moment it is deemed to have been filed or served}

Any system of electronic service shall be able to provide proof that service has been carried out properly and at what moment. National laws deal with the question of the proof of service in a very general manner: they assume that the technical systems will be equipped with proper tools to generate an acknowledgement of receipt, which can be automatic (like in England or in Spain), or which has to be sent back by the addressee (like in Germany), or they rely on the information provided by the system concerning the moment in which the addressee got access to the sent message (like in Brazil, in France or, in a certain way, in Italy). Confidence in technical elements is once again required.

In particular, it is important to be able to prove the time at which electronic filing or service is deemed to have taken place, because in respect of the filing of documents by the parties, this activity is normally subject to time limits, and in respect of the service of decisions on the parties, this normally marks the start of a fresh time limit within which to reply.

One might expect that the use of electronic systems, which avoid the need to attend in person at the court house, would eventually lead to the disappearance of the restrictions imposed by business days or working hours. However, the fact is that most legal systems have not yet made this leap and continue to attach importance to the requirement that any electronic filing or service carried out on non-business days or at 
non-working hours should be linked to business days and working hours, normally the next business day at the start of the working hours (as in the case of Spain, or in England when using the online forms service, or in Brazil, in the case of notifications addressed to the parties): if working hours end at 20:00 hours, for example, a dispatch sent at 23:00 hours on the day on which a time limit expires is deemed to have been made at 08:00 hours on the next day, which would make it out of time.

However, looking to the future, it is not hard to envisage that the widespread implementation of electronic service will end up affecting the rules on calculating time limits in proceedings. It is possible that the notion of 'business day' and 'working hours' will continue to apply to all activities that take place physically in court, performed by officials subject to business days and working hours. But their significance will be eroded for litigants and for the independent professionals who work for them and who are free to define their own working hours: it does not seem logical to require litigants and their lawyers to abide by working hours when filing documents electronically, when reality shows that their work goes on beyond the hours at which the courts are open, and that the electronic systems can operate 24 hours a day. As has been seen, the legislation in most countries has not yet caught up with this reality. Fortunately, some examples of common sense can be found in English law - but only when EWS is used - or in Brazilian law and in the rules of the ECHR, in the case of filing pleadings with the court. It is to be hoped that other legislators will follow the same path.

\subsection{The voluntary nature of the electronic-notification mechanisms}

The majority of national legal systems emphasize the voluntary nature that the use of electronic means for the filing of documents and service of notices must have. This voluntary nature is even more pronounced when it comes to the receipt of notices: sometimes there is an express requirement (France, Italy, Germany, United States, England), and in other cases there is an indirect approach, where the use of the system is made conditional on the prior registration of the user, and such registration is not compulsory (Austria or Brazil). Spain would appear to be an exception to this rule, where the electronic system is designed to be compulsory as and when it becomes available to the courts, and also in France, where it has shortly become compulsory in certain types of litigation. When it comes to supra-national courts, its voluntary nature is an absolute rule.

The question arises of whether it is possible to make the leap towards making the use of these systems compulsory - or at least towards increasing the degree of compulsion. In general terms, such a change would only be possible if various circumstances arise:

- On the part of the States, it is necessary that they should design an e-filing and eservice system that is adequate and that is capable of handling the entire volume of communications that are carried out every day.

- On the part of the courts, it is necessary that they should all be equipped with computer systems that allow the use of the e-filing and e-service system designed in each country, and that court officials should all be trained to use it properly.

- On the part of litigants, it is necessary for one of the two following situations to arise: either there must be a duty that all persons or legal professionals should have computer equipment and sufficient computer skills to use them, or it should be verified 
that all persons or legal professionals are already de facto in possession of the said means and of the said computer skills.

It is obvious that currently not all private individuals -potential litigants- are in possession of computer equipment and computer skills, but at least in those countries that have acquired a certain level of economic and social development, their lawyers and legal representatives do have them - or can be required to have them.

Therefore, at the moment, it is only possible to envisage a gradual generalization of the mechanisms of e-service where these rely on legal professionals. It is clear that the use of these systems seeks to reduce the workload of court officials and the postal services. It is however indispensable that other professionals (such as huissiers in France or procuradores in Spain) can become a part of the system, as the reference point for electronic notices to or from their client.

Ultimately, in certain geographical contexts, there are not that many obstacles to advancing towards the generalization of electronic communication systems in court proceedings.

\subsection{The possibility of using electronic means to serve the writ commencing the proceedings}

One of the most difficult questions -at the present moment, but also when facing a future mandatory use of electronic service- is the possibility of validly using electronic means of communication to serve on the defendant the writ or any equivalent document commencing the proceedings, which is nowadays only allowed in some countries if the defendant has previously accepted it [England, with rules 6.3 (1)(d) and 6.23 (6) CPR and Practice Direction 6A].

Indeed, the electronic service of documents within the framework of legal proceedings ought to be simple and relatively problem-free, once the parties to the proceedings have been identified before the court and have supplied to the court or to the other parties their corresponding electronic addresses. Where appropriate, this will involve having a user ID on the communications system that has been designed.

In the case of the party commencing proceedings, the system is quite simple: whilst it is true that litigants cannot be required to be in possession of the means necessary for the receipt of documents served electronically, this can be required of their lawyers or representatives, at least in countries with a medium economic and social development. Therefore, difficulties would only arise within a small segment, that of litigation where legal representation by a lawyer is not required.

In the case of defendants, the same is true, but only once the addressee of the claim has already been reached by the originating writ or similar document: even if he does not possess electronic means of communication, his lawyer or representative can be required to possess such means for the remainder of the proceedings.

It is clear that this allows proceedings to be managed in a much more streamlined way. But any absolute generalization on the use of the electronic service of documents will require that it should also be possible to use it to serve the originating writ on the defendant: it is of the utmost usefulness that it should be possible to serve the writ commencing the proceedings validly by electronic means. The use of the electronic service of documents in proceedings entails significant benefits, specially the saving of time; however, experience has shown that the most time is wasted in the service of the 
originating writ on the defendant, and so any savings will only be clearly observable and significant once it is possible to serve the defendant with the originating writ electronically.

There are still a lot of obstacles to overcome on this point: specifically, we must make the leap that will allow the creation of the duty -rectius, the burden- on all litigants to be in possession of an 'official' active electronic address in which they could be served of judicial documents, even if they wouldn't want to.

Currently all litigants (both private individuals and bodies corporate) are already under a duty to have an official domicile, which serves -amongst other things- as a channel for our relationship with public bodies. When it comes to Justice, and with regard to procedural purposes, this duty of being physically located is the basis of the legitimacy of systems where notices are -falsely- presumed served if published in an official gazette or done in some "special" ways, admitted by the procedural law of many countries in order to make possible procedures against defenders that can not be located. Therefore it is necessary to consider the possibility of taking one further step and establishing a duty on citizens to be in possession of an 'electronic domicile' to which official notices may be served -including those pertaining to court proceedingsprovided that the conditions laid down by law are met: for example, there may be a requirement for an electronic acknowledgement of receipt or the like before it may be deemed that service has been successful.

I think that the introduction of a generic duty of being in possession of an electronic domicile and of being 'electronically located' for official purposes -just as, whether we like it or not, we are physically located in our homes- is currently justifiable at certain levels: I refer to companies and to private individuals who work as professionals. In the internet era, the public authorities may legitimately require all those who seek to pursue an economic activity in the marketplace to be in possession of an electronic address, just as they are required to keep their books and to have a physical domicile. It would be easy to extend this duty to the possibility of using this address to serve an initial electronic notice of the existence of the proceedings, which would allow a significant saving in time and energy.

Extending this duty to private individuals remains a utopian idea, especially in certain geographical areas. Looking to the future, governments ought to make an effort towards achieving the goal of all citizens being in possession of an accessible internet address where documents may be served electronically. In any event, and whilst the level of development that allows the introduction of a general duty to be in possession of an electronic address is reached, legal systems should allow originating writs to be served electronically in those cases where the e-mail address of the addressee is already known and it is possible to prove that it is current and in use (and this would be quite easy, e.g. where this address has been used by the party in previous notices served on the other party). However, the success of this first notice, at least for the moment, should maybe remain conditioned to acknowledgement of receipt from the addressee.

\subsection{International electronic service of documents? The example of the European procedures}

The electronic service of documents is also extremely useful at an international level: borders are no barrier to the internet and to secure systems of electronic communication, 
and this is something that should be taken advantage of for the benefit of procedural efficiency.

In particular, and in relation to the questions examined in the foregoing paragraphs, one can envisage the use of electronic mechanisms for the international service of notices. Given that the internet knows no geographical boundaries, the use of e-mail could allow e-service of notices abroad directly, without the need to resort to the standard mechanisms of international judicial co-operation in this matter.

It is evident, however, that there is a problem: normally, international co-operation is necessary in order to serve the originating writ on the defendant, which is precisely the service that is most complex and for which it is most difficult to use electronic service mechanisms from the start (as has just been seen).

This is maybe the reason why electronic means of communication are absent from all the conventions and legal instruments regulating judicial international cooperation in the area of the service of documents. For obvious chronological reasons there are no references to e-service in The Hague Convention of 1 March 1954 on Civil Procedure, in The Hague Convention of 15 November 1965 on the Service Abroad of Judicial and Extrajudicial Documents in Civil or Commercial Matters, nor in the Inter-American Convention on Letters Rogatory of 30 January 1975.

But there are also no direct references to e-service in the most modern rule, Regulation (EC) No 1393/2007 of 13 November 2007 on the service in the Member States of judicial and extrajudicial documents in civil or commercial matters (service of documents), and repealing Council Regulation (EC) No 1348/2000. It is indeed notable that such a recent text should not contain an express reference to electronic service. The only possibility -although only in accordance with national legislation-is that once the documents that are to be served have been received by the authority responsible for carrying this out, this can then be done electronically: but in this case it would not be the international notification that was carried out electronically, but the internal notification.

For this reason, it might be reasonable to transpose the English model (direct service of the claim by e-mail in those cases where the addressee has consented to this prior to the litigation) to the field of international notifications - at least in the context of closelyrelated regions, such as Europe. In this regard, it could also make sense to use certain presumptions (similar to those of English Law), based on the premise that a private individual who or body corporate which has provided an e-mail address as a valid address for commercial relations is deemed to have given such consent. It is obvious that the practical impact of a provision such as the foregoing would be limited, but it is in any event reasonable that it should be expressly envisaged. In fact, if one takes a closer look, it is something that is perfectly possible nowadays in accordance with internal regulations which -as in England- allow for this, without any need for it to be envisaged in supra-national regulations: where a party with residence in Spain, but with business interests in England, consents in writing to electronic service, an originating writ may be served directly by electronic means, without any need to rely on the instruments envisaged in the European Regulation.

However, general regulations would be desirable in order to provide legal certainty to a sector where the differences between States can have repercussions for the recognition and enforcement of foreign judgements. In effect, within the scope of the Brussels 
Convention (article 27.2) and Regulation No. 44/2001 (article 34.2), the recognition and enforcement of judgements given in the absence of the accused can be rejected if it is held that the originating writ was not properly served and with sufficient time to allow the defendant to prepare his defence ${ }^{45}$. But it is the court of the enforcement State that must decide whether or not the notification issued in the State of origin complies with the requirements, irrespective of whether or not service was carried out in due manner pursuant to the laws of the State of origin ${ }^{46}$. Therefore, a situation could arise where an electronic notification could be validly carried out in England, but subsequently recognition could be denied in Spain because a Spanish judge could decide that the notification was invalid. Therefore there is a clear need to have common standards with regard to the manner in which the originating writ ought to be served. The setting of these common European standards ${ }^{47}$ would also serve to establish a certain level of harmonization between national laws and could also be the opportunity to resolve problems regarding the language of the documents being served or filed and the right of the addressee to validly reject the notification ${ }^{48}$.

Clear examples of what has been said are supplied by the European Regulations on civil procedure ruling the European Enforcement Order, the European Order for Payment and the European Small Claims Procedure.

\section{a) Electronic service as a condition for the expedition of a European enforcement order}

According to Regulation No 805/2004 creating a European Enforcement Order for uncontested claims, certain judgments may be certified as European Enforcement Orders if they have been rendered in procedures where the debtor did not contest a money claim: the judicial decision is certified as a EEO in the State of origin and it will be directly enforceable in any other Member State, without the need for a declaration of enforceability in the Member State of enforcement prior to recognition and enforcement.

\footnotetext{
${ }^{45}$ See, generally, the Judgment of the European Court of Justice, Lancray v Peters und Sickert (C-305/88) [1990] ECR I-02725.

${ }^{46}$ See the Judgments of the European Court of Justice Klomps v Michel (166/80) [1981] ECR 01593 and Mærsk Olie \& Gas 14 (C-39/02) [2004] ECR I-09657.

${ }^{47}$ And I shall recall that Article $81.2 \mathrm{f}$ ) of the Treaty on the Functioning of the European Union allows the European Parliament and the Council to «adopt measures, particularly when necessary for the proper functioning of the internal market, aimed at ensuring: (f) the elimination of obstacles to the proper functioning of civil proceedings, if necessary by promoting the compatibility of the rules on civil procedure applicable in the Member States».

${ }^{48}$ There are two important decisions of the European Court of Justice interpreting Regulation No 1348/2000: Leffler (C-443/03) [2005] ECR I-09611, regarding the possibility of the sender to remedy a faulty service -on the ground that it is not in an official language of the Member State addressed or in a language of the Member State of transmission which the addressee understands-; and Weiss und Partner (C-14/07) [2008] ECR I-03367, clarifying that it is not necessary to provide a translation of documentary evidence attached to the claim, when those documents have a purely evidential function and are not necessary for understanding the subject matter of the claim and the cause of action. Besides, and this time concerning the interpretation of Council Directive 76/308/EEC of 15 March 1976 on mutual assistance for the recovery of claims relating to certain levies, duties, taxes and other measures, reference must be done to the recent Judgment Kyrian (C-233/08) [2010], stating that the addressee of an instrument permitting enforcement must receive the notification of that instrument in an official language of the Member State in which the requested authority is situated.
} 
A judgment on a claim that is uncontested can be certified as a European Enforcement Order only if the court proceedings in the Member State of origin met certain procedural requirements and among them the method followed to serve on the debtor the document instituting the proceedings. Art. 13.1 d) of EEO-Regulation accepts service by electronic means such as e-mail, if it is attested by an acknowledgement of receipt including the date of receipt, which is signed and returned by the debtor. Art. $14.1 \mathrm{f}$ ) EEO-Regulation goes further and considers valid service by electronics means without proof of receipt by the debtor if it is attested by an automatic confirmation of delivery, "provided that the debtor has expressly accepted this method of service in advance".

Since there is no requirement that the debtor is domiciled in the Member State of origin, this could be a way to carry out an "undercover" international electronic service of documents. And the debtor will not be allowed to apply afterwards for the withdrawal of the European Enforcement Order certificate adducing that service was made on him by electronic means.

\section{b) Electronic service on the debtor in the European Order foy Payment procedure and in the European Small Claims procedure}

It is also necessary to take account of what is established in the rules regarding the European Order for Payment procedure (Regulation No 1896/2006 of 12 December 2006 creating a European order for payment procedure) and the European Small Claims procedure (Regulation No 861/2007 of 11 July 2007 establishing a European Small Claims Procedure). Both procedures apply only to cross-border cases, which means that at least one of the parties is domiciled or habitually resident in a Member State other than the Member State of the court seised. Therefore there will be the need to carry out cross-border service of documents and the European legislator has been aware of the possibility of using electronic means as a way to avoid the need to use traditional systems of international service of documents.

(i) The European Order for Payment procedure is based on an application lodged by the creditor, upon which, if certain requirements are met, the court will issue a European order for payment addressed to the debtor. If the debtor does not pay nor lodges a statement of opposition within 30 days, the court will declare the European order for payment enforceable in all Member States. Two communications are at least necessary and one of them may have a cross-border nature:

- First there is the lodging of the creditor's application. This application may be submitted in paper form or "by any other means of communication, including electronic, accepted by the Member State of origin and available to the court of origin" (Art. 7.5 EOP-Regulation). There is hence a place for an e-filing of the request, which is possible, according to the European Judicial Atlas in Civil Matters, in several countries ${ }^{49}$.

\footnotetext{
${ }^{49}$ It is clearly permitted in France, Slovenia, Cyprus, Estonia and Finland. In Slovakia and in the Czech Republic, if the application is filed without advanced electronic signature, the original copies of the forms must be sent no later than three days after submission. Austria permits using the WebERV -open to any person and company-, but doesn't admit e-mails. In the Netherlands the electronic submission of applications for a European Order for Payment is permitted, as long as this is provided for in the court's procedural rules, but currently none of the courts provides for this possibility. Germany is currently working on the development of an IT system which should make it possible to submit European payment order applications and objections electronically, but it doesn't seem to be available so far. The situation is similar in England and Wales, in Northern Ireland and in Scotland.
} 
- Once the European order for payment has been issued, it must be served on the debtor: this service originates the debtor's burden to pay or to contest the claim. Service on the defendant may be effected by electronic means such as e-mail, attested by an acknowledgement of receipt, including the date of receipt, which is signed and returned by the defendant [Art. 13 d) EOP-Regulation]. But it may also be served without proof of receipt by the defendant using electronic means attested by an automatic confirmation of delivery, provided that the defendant has expressly accepted this method of service in advance [Art. $14.1 \mathrm{f}$ ) EOP-Regulation]. It is important, therefore, to notice that a simple automatic confirmation of delivery could be enough to consider that the European order for payment has been correctly served and, eventually, to render it enforceable if the debtor doesn't pay nor contests the claim.

The Regulation, however, includes the general requirement that service has to be made on the defendant in accordance with the national law of the State in which service is to be effected: national law, thus, should admit this kind of service and this will reduce the practical effectiveness of the rule. But it reveals clearly where the European legislator has placed the minimum standards for electronic service of documents.

(ii) The European Small Claims procedure is a written procedure allowing the recovery of sums less than EUR 2000 and based on the use of standard forms. The key for a proper functioning of the procedure is the lodging of a standard claim form with the competent court and notifying the defendant, so he can submit a standard answer form. Both notifications may be of a cross-border nature and for both of them the use of electronic means of communication is permitted.

- To file his claim the claimant may use any means of communication acceptable to the Member State in which the action is taken (Art. 4.1 ESCP-Regulation) and this includes e-mail ${ }^{50}$.

- The ordinary way to serve the claim on the defendant shall be postal service attested by an acknowledgement of receipt including the date of receipt (Art. 13 ESCPRegulation). If service by this means in not possible, then it may be effected by any of the methods provided for in Articles 13 or 14 of EEO-Regulation: e-mail will be therefore admissible, even without proof of receipt by the debtor, if there is an automatic confirmation of delivery, provided that the defendant has expressly accepted this method of service in advance (and without the condition, set by the EOPRegulation, that this method of service is in accordance with the national law of the State in which service is to be effected).

(iii) The ruling of this question made by EOP and ESCP-Regulations has a very strong significance, when compared to what is established in the EEO-Regulation. In fact EEO-Regulation merely states the minimum standards that must be met in order to give immediate cross-border enforceability to certain judicial decisions. EOP and ESCP-

\footnotetext{
50 According to the European Judicial Atlas in Civil Matters, this kind of electronic filing is clearly permitted in the following countries: Portugal, France, Cyprus, Slovenia, Estonia and Finland. In Austria only WebERV can be used, but not e-mail. In the Netherlands the electronic submission is legally possible, but in practice it is not available. In Germany an electronic submission of the claim is only possible in the regions of Brandenburg, Bremen and Hesse. In Slovakia and in the Czech Republic, if the claim is filed without advanced electronic signature, the original copies of the form must be sent no later than three days after submission. England and Wales, Northern Ireland and Scotland are currently working on the development of an IT system which should make it possible to submit the claim electronically, but it doesn't seem to be available so far.
} 
Regulations go a step further and rule directly the methods considered aceptable to serve on the defendant the document instituting the proceedings: the European legislator considers that electronic service without proof of receipt by the defendant, merely attested by an automatic confirmation of delivery, is sufficient to create the burdens associated to the defendant's position, provided that he has expressly accepted this method of service in advance. Therefore, the harmonizing effect associated with European procedural rules may lead to the generalization of this criterion across the national legal systems.

Given this eventual approach, it would be important to have a clear definition of what is meant by 'having expressly accepted in advance' a notification method such as eservice. The Court of Justice of the European Union, in its judgment of 8 May 2008 delivered in the case Weiss und Partner (C-14/07), held that "the fact that the addressee of a document served has agreed in a contract concluded with the applicant in the course of his business that correspondence is to be conducted in the language of the Member State of transmission does not give rise to a presumption of knowledge of that language, but is evidence which the court may take into account in determining whether that addressee understands the language of the Member State of transmission". Likewise, it could be argued that agreeing that any communications linked to the business or contractual relations are to be conducted by e-mail to a specific e-mail address is sufficient evidence that the service of any claims linked to the same business relations may also be served to the same e-mail address by electronic means.

And it would also be necessary to bear in mind -and to take measures to prevent- the danger that in certain contractual relations, a priori acceptance of this kind of service might be imposed on the weaker party, despite not being familiar with them or not having the tools to access their electronic mailboxes frequently.

In addition, we can not forget the difficulties raised by the cross-border nature of the service (for example, those relating to languages). It is clear that these problems are not new and that the guidelines for resolving them are already contained in the normative instruments that govern traditional cross-border service of documents: therefore it would only be necessary to adapt these tools to the electronic nature of the service.

\subsection{Electronic communication and international judicial cooperation}

In general, international cooperation systems, both civil and criminal, require communication between parties located in different States: the parties that need to communicate and to file requests and documents lato sensu might be judicial authorities or 'central authorities' in charge of overseeing cooperation, in accordance with the subject matter and the applicable normative instruments.

It is clear, in this context, that it is convenient to encourage the use of electronic means as tools for transmitting any pertinent requests for cooperation or actions between the parties participating in international judicial cooperation, at least for two reasons. Firstly, because cooperation would function more swiftly, especially if one takes into account the need to complete or correct documents of all kinds. And secondly, because this would require that any request for judicial cooperation, as well as any complementary documentation, should be in electronic format, which would in turn simplify the subsequent treatment and circulation of the request at an internal level, both 
in the plaintiff and in the defendant States. As we shall see below, this is one of the objectives of the European institutions in their plans for the promotion of e-Justice ${ }^{51}$.

\section{a) Electronic communication and international judicial cooperation in civil matters}

In civil and commercial matters the use of electronic mail as a mean to activate the judicial international cooperation can find a place, at least within the European Union, for both the service of documents and the taking of evidence abroad.

As to service abroad, according to Art. 4 of the Regulation $n^{\circ} 1393 / 2007$ on the service in the Member States of judicial and extrajudicial documents in civil or commercial matters (service of documents), the agencies involved in cooperation shall transmit any document "directly and as soon as possible", and this "by any appropriate means, provided that the content of the document received is true and faithful to that of the document forwarded and that all information in it is easily legible". The Member States have communicated to the European Commission which are the means of communication they accept to receive requests of cooperation. Some of them -not many, though- accept electronic mail for this purpose ${ }^{52}$.

Regarding the taking of evidence abroad Art. 6 of the Regulation (EC) $n^{\circ}$. 1206/2001 of 28 May 2001 on cooperation between the courts of the Member States in the taking of evidence in civil or commercial matters, states that "requests and communications shall be transmitted by the swiftest possible means, which the requested Member State has indicated it can accept. The transmission may be carried out by any appropriate means, provided that the document received accurately reflects the content of the document forwarded and that all information in it is legible." As a result of this provision, many Member States have communicated to the Commission their willingness to admit requests transmitted per e-mail ${ }^{53}$.

As a matter of fact, the European Action Plans on e-Justice include the proposal to introduce the use of electronic means of communication into the Regulations on taking of evidence and service of documents, taking advantage of the construction of secure networks for the transmission of information between courts ${ }^{54}$.

\section{b) Electronic communication and international judicial cooperation in criminal matters}

Developments in matters of criminal judicial co-operation are event greater, at least within the scope of the European Union, thanks for the most part to the existence of the European Judicial Network in criminal matters ${ }^{55}$. The Decision that sets it up envisages

51 See the Communication from the Commission to the Council, the European Parliament and the European Economic and Social Committee, "Towards a European e-Justice Strategy", 30 May 2008, $\operatorname{COM}(2008) 329$ final; the Resolution of the European Parliament of 18 December 2008 with recommendations to the Commission on e-Justice [2008/2125(INI)]; and the Council's Multi-annual European e-Justice action plan 2009-2013 (OJ C 75, 31 March 2009).

52 That's what happens in Belgium, the Netherlands, Hungary, Denmark, Finland, Estonia, the Czech Republic and Cyprus; Latvia and Malta accept requests sent by e-mail if they are also sent by ordinary mail; Germany accepts e-mail only for informal communications.

53 This happens in Portugal, France, Malta, Greece, Slovakia, the Czech Republic, Latvia, Estonia, Finland, Scotland and Ireland. There is no match with the countries mentioned in the precedent footnote!

${ }^{54}$ See the Resolution of the European Parliament (Recommendation 2, section 2).

${ }^{55}$ Council Decision 2008/976/JHA of 16 December 2008 on the European Judicial Network (OJ L 348, 24 December 2008). 
the creation of a secure telecommunications connection for the operational tasks of the contact points on the Network, the cost of which is to be funded by the general budget of the European Union. This secure telecommunications connection will allow the flow of data and of applications for judicial cooperation between Member States. Therefore, it constitutes a tool at the service of the transmission of letters rogatory and applications for cooperation or recognition as provided for in the various European texts or agreements and which are applicable to criminal judicial cooperation between Member States.

In order to articulate the supply of information and the use of the communications network, there exists an internet Portal for the European Judicial Network in criminal matters ${ }^{56}$. The features of the portal serve to facilitate international judicial cooperation in criminal matters, whether pursuant to the normative texts approved by the European Union, or also on the basis of other normative texts: now then, the principal participants in the cooperation -both plaintiffs and defendants- must always be Member States. Amongst other tools, the portal features a judicial Atlas which allows the judicial authority of the other State to which the application for cooperation ought to be addressed to be identified, in accordance with the type of activity in question and the normative framework being used ${ }^{57}$. In addition, there is also the Compendium Wizard, which can be used to create an on-line letter rogatory or equivalent application, and where appropriate, to dispatch it securely to the addressee ${ }^{58}$. Furthermore, and more specifically, an alternative Atlas and Compendium Wizard have been designed in order to assist in implementing the European provisions on the European arrest warrant. In any event, the European institutions continue to encourage the creation of a secure network for the exchange of information between judicial authorities, progressing on the basis of the various versions of the E-POC project developed by Eurojust.

Electronic service may indeed become the standard form for the service of documents between judicial bodies at all levels of international judicial cooperation. A significant part of the normative instruments that govern international judicial cooperation encourage direct service between courts, or service through central authorities acting swiftly. Electronic service may be a suitable tool for the transfer of those documents through which international cooperation operates, both in civil and in criminal matters. For this purpose, it is necessary to set up mechanisms that will allow documents to be served in secure conditions which are also required at an internal level; and it is also necessary to set up information systems, such as the European Judicial Atlas, which will allow the use thereof to be optimized by way of compiling a directory or catalogue with the electronic addresses of all bodies and authorities involved. The best examples of how it is possible to progress in this path are -there is no doubt about it- the works of European institutions.

\section{FINAL REMARKS}

When they function properly, electronic communication mechanisms allow the court and the parties to save time and money, and contribute to more agile and efficient

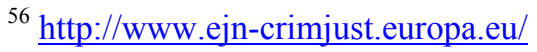

${ }^{57} \mathrm{http}: / /$ www.ejn-crimjust.europa.eu/atlas_advanced.aspx

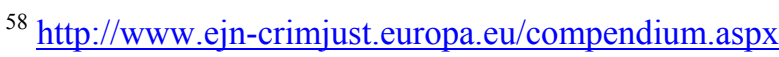


proceedings. For this reason, it is convenient to encourage their implementation and to make their use widespread. Indeed, they have significant potential in cross-border situations and in streamlining international judicial cooperation: their use should also be encouraged in these sectors.

It may be seen, however, that legal development is variable in each State and that similar problems are sometimes met with different solutions. For this reason, it would be recommendable to attain a certain level of harmonization on this point, at least within integrated regional environments, such as the European Union. This harmonization, in my opinion, should consist in the setting of minimum standards at various levels: the technical requirements that ensure the reliability of the electronic communications system and the conditions under which e-service and e-filing may be carried out - in particular the requirements that must be met in order for them to be deemed to be validly carried out.

In the field of electronic notification there are certain 'red lines' that cannot be crossed or that can only be crossed if certain safeguards are in place and there are clear rules that ensure that the safeguards are upheld: electronic service of the originating writ on the defendant, especially in cross-border cases, is the clearest example.

In general, one must be aware of the dangers that the automation of human activities might pose for procedural rights, and we must ensure that the development of judicial activities in electronic form does not covertly or unwittingly end up infringing the rights of litigants. Therefore, the roll-out of e-Justice should not be an end in itself, but rather a means of allowing the Justice system to better perform its function of safeguarding the legal system and protecting rights ${ }^{59}$.

For this reason, I would like to emphasize the idea, mentioned at the start of this work, that e-Justice is made up of tools at the service of Justice, amongst which are included electronic communications: but the tools should never dictate the development of the purpose they serve. The process of computerizing all kinds of activities, however, has made us accustomed to just the opposite: it is commonplace to come across obstacles to carrying out certain activities where the computer system controlling them does not envisage them. It is evident that this should not occur in the field of Justice: it would be intolerable that the legitimate exercise of rights, or that their proper legal protection, should be precluded or hindered by the deficiencies of the software tools available to the courts. Therefore it would be sensible for the phenomenon of the implementation of eJustice to be accompanied by a general safeguard or get-out clause: litigants shall always have the right for judicial bodies to carry out all activities necessary for the protection of their rights by 'traditional' methods, where there should be a failure, deficiency, or design defect in a computerized system for court procedure: this maxim should be upheld at all levels, including e-service and e-filing.

Recently, the European Court of Human Rights has recognised that the decision of one national court not to allow a litigant to use the electronic systems envisaged by law specifically, the electronic filing of originating writs- was contrary to the right to have

\footnotetext{
${ }^{59}$ In that sense, see the Opinion of the European Economic and Social Committee on the Communication from the Commission to the Council, the European Parliament and the European Economic and Social Committee: Towards a European e-Justice Strategy, 30 September 2009 (Doc. INT/457, 1455/2009, section 4.3).
} 
access to the courts enshrined at article $6.1 \mathrm{ECHR}^{60}$. In the same manner, a refusal by a court to allow the use of non-electronic mechanisms in the event of the failure or malfunction of the electronic systems, even if they have been defined by law as being compulsory for the performance of a particular step in proceedings, could also amount to a breach of the right to a fair trial.

\footnotetext{
${ }^{60}$ Lawyer Partners A.S. v. Slovakia (16 June 2009).
} 